\title{
Combined assimilation of IASI and MLS observations to constrain tropospheric and stratospheric ozone in a global chemical transport model
}

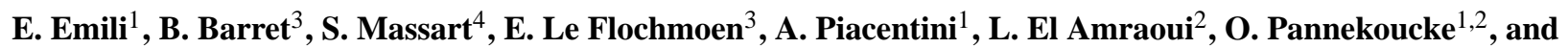 \\ D. Cariolle ${ }^{1,2}$ \\ ${ }^{1}$ CERFACS and CNRS, URA1875, Toulouse, France \\ ${ }^{2}$ CNRM-GAME, Météo-France and CNRS, UMR3589, Toulouse, France \\ ${ }^{3}$ Laboratoire d'Aérologie/OMP, Université de Toulouse and CNRS, UMR5560, Toulouse, France \\ ${ }^{4}$ ECMWF, Reading, UK
}

Correspondence to: E. Emili (emili@ cerfacs.fr)

Received: 15 July 2013 - Published in Atmos. Chem. Phys. Discuss.: 20 August 2013

Revised: 27 November 2013 - Accepted: 29 November 2013 - Published: 8 January 2014

\begin{abstract}
Accurate and temporally resolved fields of freetroposphere ozone are of major importance to quantify the intercontinental transport of pollution and the ozone radiative forcing. We consider a global chemical transport model (MOdèle de Chimie Atmosphérique à Grande Échelle, MOCAGE) in combination with a linear ozone chemistry scheme to examine the impact of assimilating observations from the Microwave Limb Sounder (MLS) and the Infrared Atmospheric Sounding Interferometer (IASI). The assimilation of the two instruments is performed by means of a variational algorithm (4D-VAR) and allows to constrain stratospheric and tropospheric ozone simultaneously. The analysis is first computed for the months of August and November 2008 and validated against ozonesonde measurements to verify the presence of observations and model biases. Furthermore, a longer analysis of 6 months (July-December 2008) showed that the combined assimilation of MLS and IASI is able to globally reduce the uncertainty (root mean square error, RMSE) of the modeled ozone columns from 30 to $15 \%$ in the upper troposphere/lower stratosphere (UTLS, 70-225 hPa). The assimilation of IASI tropospheric ozone observations (1000-225 hPa columns, TOC - tropospheric $\mathrm{O}_{3}$ column) decreases the RMSE of the model from 40 to $20 \%$ in the tropics $\left(30^{\circ} \mathrm{S}-30^{\circ} \mathrm{N}\right)$, whereas it is not effective at higher latitudes. Results are confirmed by a comparison with additional ozone data sets like the Measurements
\end{abstract}

of OZone and wAter vapour by aIrbus in-service airCraft (MOZAIC) data, the Ozone Monitoring Instrument (OMI) total ozone columns and several high-altitude surface measurements. Finally, the analysis is found to be insensitive to the assimilation parameters. We conclude that the combination of a simplified ozone chemistry scheme with frequent satellite observations is a valuable tool for the longterm analysis of stratospheric and free-tropospheric ozone.

\section{Introduction}

Tropospheric ozone $\left(\mathrm{O}_{3}\right)$ is the third most important gas in its contribution to the global greenhouse effect after $\mathrm{CO}_{2}$ and $\mathrm{CH}_{4}$ (Solomon et al., 2007). It is also a major pollutant in the planetary boundary layer, with adverse effects on humans health (Brunekreef and Holgate, 2002) and plants (Avnery et al., 2011). Its production is mainly driven by emissions of primary pollutants such as nitrogen oxides $\left(\mathrm{NO}_{\mathrm{x}}\right)$, carbon monoxide (CO) and volatile organic compounds (VOCs), followed by photolysis and nonlinear chemistry reactions (Seinfeld and Pandis, 1998). Since it has an average lifetime of about two weeks, it can be efficiently transported for several thousands of kilometers in the free troposphere (Zhang et al., 2008; Ambrose et al., 2011). Quantifying the impact of tropospheric ozone transport is especially important for those 
countries that, despite air-quality related regulations, experience a significant ozone background increase (Jaffe and Ray, 2007; Tanimoto, 2009). Moreover, intrusions of ozonerich air from the stratosphere via stratosphere-troposphere exchanges (STE) are among the principal causes of high free-troposphere ozone episodes (Stohl et al., 2003; Barré et al., 2012). Therefore, a precise characterization of both low-stratosphere and tropospheric ozone is required to properly quantify ozone transport.

Ozonesondes provide observations of tropospheric and stratospheric ozone with high vertical resolution (Komhyr et al., 1995), but their geographical distribution is sparse and they are not very frequent in time. Satellite observations of ozone are available since the early 70 s (Fioletov et al., 2002) but they provided mainly stratospheric ozone profiles or total columns. Since the stratospheric ozone concentration is higher than the tropospheric one by several orders of magnitude, total column retrievals do not provide a strong sensitivity to tropospheric ozone. Several studies derived tropospheric ozone columns by means of subtracting the measured stratospheric amount from the total column (Ziemke et al., 2006; Kar et al., 2010; Yang et al., 2010). However, these techniques are limited by the difficulties that arise from combining data from instruments with different calibration and spatiotemporal resolutions (Ziemke et al., 2011). The latest generation of thermal infrared spectrometers, onboard low Earth orbit (LEO) satellites, is able to capture the tropospheric ozone signature (Eremenko et al., 2008; Boynard et al., 2009; Barret et al., 2011; Tang and Prather, 2012). The Tropospheric Emission Spectrometer (TES) provides for example almost two pieces of independent information (degrees of freedom for signal, DFS) in the troposphere (Zhang et al., 2010) with a global coverage in 16 days. The Infrared Atmospheric Sounding Interferometer (IASI) allows a daily global coverage at very high spatial resolution $(12 \mathrm{~km}$ for nadir observations), with a slightly reduced number of tropospheric DFS ( $\sim 1$, Dufour et al., 2012), although the DFS value might also be sensitive to the choice of the tropopause height and the retrieval technique. In general, satellite data permits to catch major features of ozone tropospheric distribution (Ziemke et al., 2009; Hegarty et al., 2010; Barret et al., 2011) but observation frequency and data gaps (e.g., due to clouds) do not allow a complete view of the underlying dynamics at short timescales (e.g., hours).

Chemical transport models (CTM), through data assimilation (DA), can ingest information from satellite observations in a coherent way (e.g., by considering the vertical sensitivity of the instrument) and use them to update the modeled 3D ozone field. Likewise, satellite retrievals themselves are normally based on the inversion of the measured radiance data with a variational approach, thus requiring an a priori profile from a model or a climatology as ancillary input (Eskes and Boersma, 2003). Data assimilation of stratospheric ozone profiles, total columns or ozone sensitive radiances is nowadays well integrated in operational meteorological models (Jackson, 2007; Dee et al., 2011), which are generally based on simplified ozone chemistry schemes (Geer et al., 2007). Assimilation of satellite $\mathrm{O}_{3}$ products has also been investigated in a number of studies with CTMs including comprehensive chemistry schemes (Geer et al., 2006; Lahoz et al., 2007b; van der A et al., 2010; Doughty et al., 2011). Furthermore, chemical data assimilation is becoming more and more part of operational services, as demonstrated by projects like the Monitoring Atmospheric Composition and Climate initiative (MACC, Inness et al., 2013).

Parrington et al. $(2008,2009)$ and Miyazaki et al. (2012) assimilated TES data to constrain tropospheric ozone. In most of the cases the bias of the respective models with regards to ozonesonde data is reduced. Few studies explored the assimilation of ozone data from IASI, which is the only sensor sensitive to tropospheric ozone and with a global daily coverage (night and day). Increasing IASI sampling with respect to TES might improve even more the analysis scores by better constraining the ozone dynamics of the model. Massart et al. (2009) assimilated IASI total columns but did not use averaging kernel information to separate tropospheric and stratospheric signals. Han and McNally (2010) assimilated IASI radiances in the European Centre for Medium-Range Weather Forecasts (ECMWF) 4D-VAR system and found a better fit of the analysis to ozone profiles from the Microwave Limb Sounder (MLS), but effects on tropospheric ozone were not discussed. Coman et al. (2012) and Barré et al. (2013) assimilated IASI 0-6 km ozone columns in two regional CTMs during a summer month and found improved ozone concentrations with respect to aircraft and surface data, but the limited availability of ozonesonde data did not allow to draw robust conclusions for the free troposphere. To our knowledge there is still no study that examined the assimilation of IASI tropospheric ozone columns globally and for long periods. Moreover, the combined assimilation of generally accurate MLS profiles in the stratosphere (Massart et al., 2012) and IASI tropospheric columns is supposed to better constrain the ozone gradients at the tropopause and the ozone exchanges between the two layers. Finally, CTMs that use detailed chemistry schemes are numerically more expensive than those using simplified linear schemes for the ozone and require emission inventories, which can be quite uncertain in some regions of the world (Ma and van Aardenne, 2004). Since the spatial coverage of IASI observations is very high and the ozone average lifetime is longer than the revisiting time of the satellite, we can expect that the degree of complexity of the CTM used for the assimilation might become less relevant. The objective of this study is to explore the potential of IASI and MLS Level 2 products to provide global analyses and forecasts of ozone, with a focus on the freetroposphere dynamics.

We assimilate ozone stratospheric profiles from MLS and tropospheric partial columns from IASI to constrain the global ozone concentration calculated with the MOdèle de Chimie Atmosphérique à Grande Échelle CTM (MOCAGE, 
Teyssèdre et al., 2007). The model can be used in combination with a linear ozone chemistry parameterization (Cariolle and Teyssèdre, 2007) or with a detailed stratosphere/troposphere chemistry. In the first case, surface emissions are not considered and a relaxation term to a climatological field is dominant in the troposphere. With this configuration we computed ozone reanalysis for the period that goes from July to December 2008.

The paper is structured as follows: Sect. 2 describes the assimilated observations and those used for the validation, the model and the assimilation algorithm are detailed in Sect. 3, Sect. 4 contains the discussion of the different simulations and their validation. Finally, conclusions are given in Sect. 5.

\section{Ozone observations}

\subsection{Assimilated observations}

\subsubsection{MLS profiles}

The MLS instrument has been flying onboard the Aura satellite in a sun-synchronous polar orbit since August 2004. It measures millimeter and sub-millimeter thermal emission at the atmospheric limb, providing vertical profiles of several atmospheric parameters (Waters et al., 2006). It allows the retrieval of about 3500 profiles per day with a nearly global latitude coverage between $82^{\circ} \mathrm{S}$ and $82^{\circ} \mathrm{N}$. The version 2.2 of the MLS ozone product is used in this study. Since the along-track distance between two successive MLS profiles $\left(1.5^{\circ}\right)$ is smaller than the model horizontal resolution $\left(2.0^{\circ}\right)$ all the profiles measured within a minute are averaged and assigned to the same grid cell. This reduces the number of profiles to about 2000 per day. A data screening based on the recommendations of Froidevaux et al. (2008) and Livesey et al. (2008) is used, as in Massart et al. (2009, 2012). Therefore, the assimilated ozone profile consists of 16 pressure levels in the range from 215 to $0.5 \mathrm{hPa}$, with four of them located in the upper troposphere/lower stratosphere (UTLS). The MLS ozone profile accuracy is the lowest in the UTLS, with biases that can be as high as $20 \%$ at $215 \mathrm{hPa}$, whereas the precision is about $5 \%$ elsewhere (Froidevaux et al., 2008). The MLS product provides a profile retrieval uncertainty based on error propagation estimations and information about the retrieval vertical sensitivity through the averaging kernels (AVK). The MLS $\mathrm{O}_{3}$ product has been already assimilated in multiple models with positive effects on models' scores in the stratosphere (Jackson and Orsolini, 2008; Stajner et al., 2008; Massart et al., 2009; El Amraoui et al., 2010; Barré et al., 2012). Since the MLS AVK peaks sharply on the retrieved pressure layers, they can be neglected in the data assimilation procedure (Massart et al., 2012). MLS ozone profiles are made available in near-real time (NRT) at the Goddard Earth Science Data and Information Services Center (http://disc.sci.gsfc.nasa.gov) and can be downloaded 2-4h after the overpass of the satellite.

\subsubsection{IASI partial columns}

IASI-A is the first IASI thermal infrared interferometer launched in 2006 onboard the Metop-A platform (Clerbaux et al., 2009). It is a meteorological sensor dedicated to the measurement of tropospheric temperature, water vapor and of the tropospheric content of a number of trace gases. Thanks to its large swath of $2200 \mathrm{~km}$, IASI enables an overpass over each location on Earth's surface twice daily. The Software for a Fast Retrieval of IASI Data (SOFRID) has been developed at Laboratoire d'Aérologie to retrieve $\mathrm{O}_{3}$ and CO profiles from IASI radiances (Barret et al., 2011). The SOFRID is based on the Radiative Transfer for TOVS (RTTOV) code and on the 1D-VAR retrieval scheme both developed for operational processing of space-borne data within the Numerical Weather Prediction - Satellite Application Facilities (NWP-SAF). For each IASI pixel, SOFRID retrieves the $\mathrm{O}_{3}$ volume mixing ratio (vmr) on 43 pressure levels between 1000 and $0.1 \mathrm{hPa}$. Nevertheless, the number of independent pieces of information or DFS of the retrieval is approximately 3 for the whole vertical profile (Dufour et al., 2012). Barret et al. (2011) have shown that IASI enables the independent determination of the tropospheric $\mathrm{O}_{3}$ column (TOC, $1000-225 \mathrm{hPa}$ ) and the UTLS (225-70 hPa) $\mathrm{O}_{3}$ column with DFS close to unity for both quantities over tropical regions. The information content analysis from Dufour et al. (2012) provides similar conclusions for both the midlatitudes and the tropics with slightly different definitions of the tropospheric and UTLS partial columns. In order to be consistent with these information content analyses and to improve the efficiency of our assimilation system, we assimilate IASI TOC instead of whole profiles. The IASI TOC was also validated against ozonesonde and airborne observations in Barret et al. (2011). Accuracies of $13 \pm 9 \%$ (relative bias \pm standard deviation) have been found at high latitudes and of $5 \pm 15 \%$ within the tropics. Therefore, a global bias correction of $10 \%$ of SOFRID values is performed, its impact being carefully discussed further in the paper. In order to remove observations with little information, pixels with TOC DFS lower than 0.6 are also screened out. The filter removes $25 \%$ of IASI retrievals globally, most of them located over ice covered surfaces, mountains or deserts, where the sensitivity of IASI to the tropospheric ozone spectral signature is significantly decreased (Boynard et al., 2009). The value of 0.6 has been chosen based on the histograms in Fig. 1 of Dufour et al. (2012). Some tests have been done with values of the threshold set to 0.4 or 0.8 but the value of 0.6 gave the best compromise in terms of removal of pixels over difficult surfaces (deserts, ice, snow) and in terms of analysis quality. The SOFRID ozone product is not yet operational but production would be possible within a delay of about $6-12 \mathrm{~h}$ after the satellite overpass. 
a)

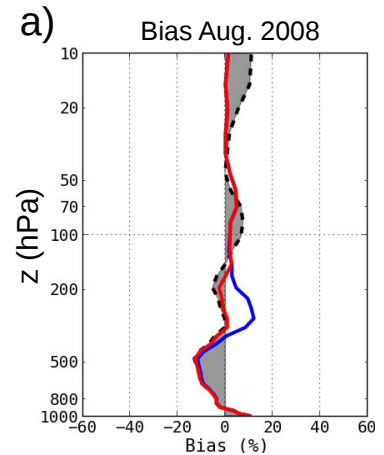

d)

b)
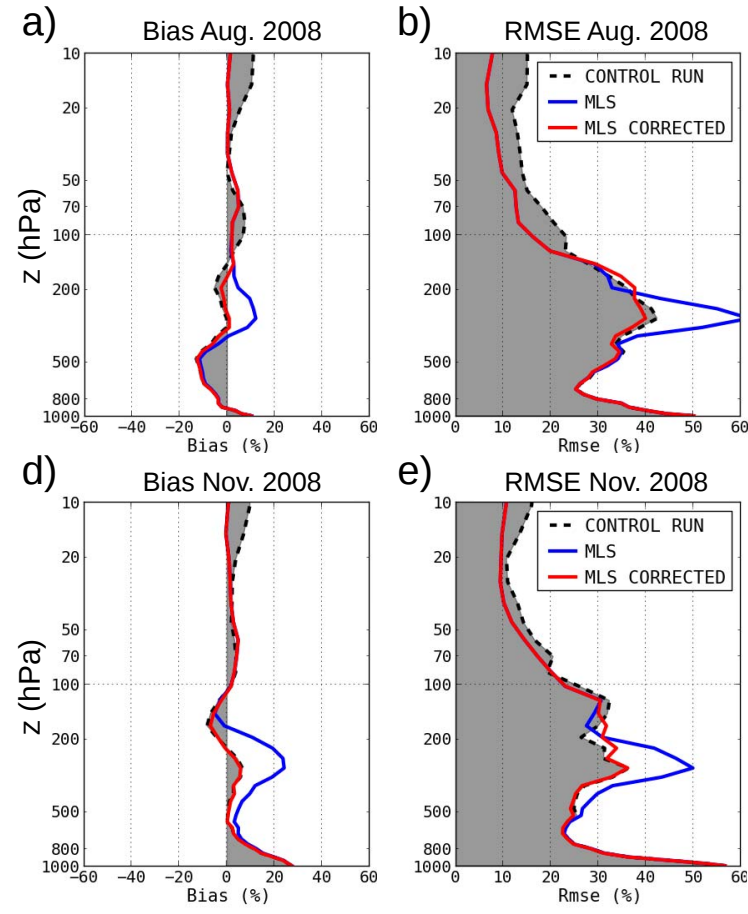

e)

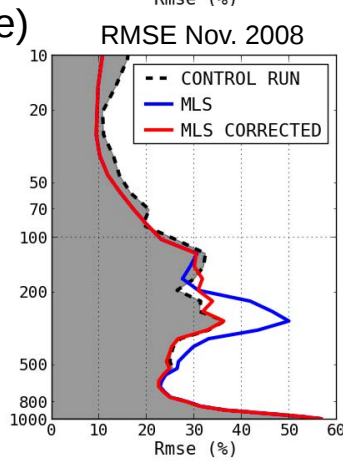

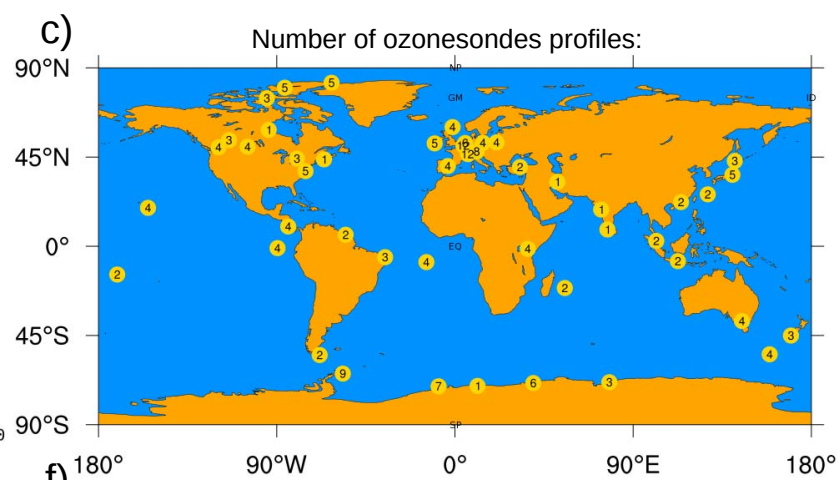

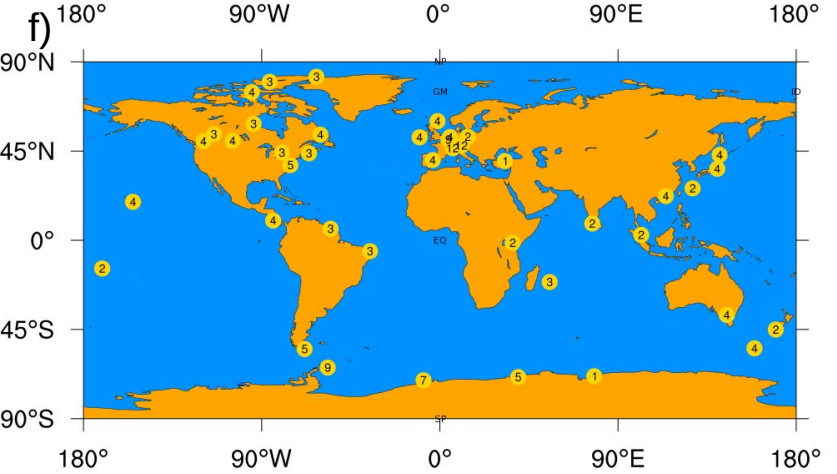

Fig. 1. Validation of control run (dotted/gray-filled lines) and MLS analyses (blue/red lines) versus ozonesondes: (a) global bias (model minus sondes) normalized with the ozone climatology for August 2008, (b) global RMSE for August 2008, (c) number of ozonesonde profiles used for the validation, (d, e, f) same as (a), (b), (c) but for November 2008. Blue lines are obtained by assimilating full MLS profiles whereas for red ones the lowermost profile level $(215 \mathrm{hPa})$ is excluded. Positive/negative values in (a), (d) mean that the model overestimates/underestimates the ozonesonde measurements.

\subsection{Validation observations}

\subsubsection{Ozonesonde profiles}

Ozonesondes are launched in many locations of the world on a weekly schedule (Fig. 1), measuring vertical profiles of ozone concentration with high vertical resolution (150-200 m) up to approximately $10 \mathrm{hPa}$. Data are collected by the World Ozone and Ultraviolet Radiation Data Centre (WOUDC, http://www.woudc.org/). Most of the sondes $(85 \%)$ are of electrochemical concentration cell (ECC) type, the rest of them being of carbon-iodide or Brewer-Mast type. This introduces some heterogeneity in the measurement network. However, it has been shown that ECC sondes, which constitute the largest part of the network, have a precision of about $5 \%$ regardless the calibration procedure employed (Thompson et al., 2003). Errors might increase to $10 \%$ where ozone amounts are low (e.g., upper troposphere and upper stratosphere, Komhyr et al., 1995). To exploit the high vertical resolution of ozonesonde data the profiles are lognormally interpolated on the coarser model grid (60 sigmahybrid levels, Sect. 3.1). Information about the horizontal drift of sonde measurements is often not given and will not be considered in the study.

\subsubsection{MOZAIC measurements}

The Measurements of OZone and wAter vapour by aIrbus inservice airCraft (MOZAIC) program (Marenco et al., 1998) was initiated in the 1990s with the aim to provide a global and accurate data set for upper-troposphere chemistry and model validation. Automated instruments mounted on-board of several commercial airplanes measure ozone concentration every $4 \mathrm{~s}$ with a precision of about \pm 2 parts per billion by volume (ppbv) or $\pm 2 \%$. Almost $90 \%$ of data is collected at the airplane cruise altitude $(\sim 200 \mathrm{hPa})$ and the remaining $10 \%$ during the takeoff/landing.

\subsubsection{OMI total columns}

The Ozone Monitoring Instrument (OMI), onboard the Aura satellite, is a nadir viewing imaging spectrometer that measures the solar radiation reflected by Earth's atmosphere and surface (Levelt et al., 2006). It makes spectral measurements in the ultraviolet/visible wavelength range at $0.5 \mathrm{~nm}$ resolution and with a very high horizontal spatial resolution $(13 \mathrm{~km} \times 24 \mathrm{~km}$ pixels $)$. In the standard global observation mode, 60 across-track ground pixels are acquired simultaneously, covering a horizontal swath approximately $2600 \mathrm{~km}$ wide, which enables measurements with a daily 
global coverage. In this study, we use the OMI Level 3 globally gridded total ozone columns (OMDOAO3e.003) available at the GIOVANNI web portal (http://disc.sci.gsfc.nasa. gov/giovanni). This product is based on the Differential Optical Absorption Spectroscopy (DOAS) inversion (Veefkind et al., 2006). OMI DOAS total ozone columns agree within $2 \%$ with ground-based observations (Balis et al., 2007), except for Southern Hemisphere (SH) high latitudes, where they are systematically overestimated by $3-5 \%$.

\subsubsection{ESRL GMD in situ measurements}

The Earth System Research Laboratory (ESRL) Global Monitoring Division (GMD, http://www.esrl.noaa.gov/gmd/) maintains several US atmospheric composition observatories and collects data from a number of other institutions (Petropavlovskikh and Oltmans, 2012). Time series of hourly ozone concentration are available at 2 sites located above $3000 \mathrm{~m}$ altitude, Mauna Loa (MLO, $19.54^{\circ} \mathrm{N}, 155.58^{\circ} \mathrm{W}$, $3397 \mathrm{~m}$ a.s.l., US) and Summit (SUM, $75.58^{\circ} \mathrm{N}, 38.48^{\circ} \mathrm{W}$, $3216 \mathrm{~m}$ a.s.l., Greenland), thus representative for the free troposphere. Since the mission of the GMD is to provide accurate long-term time series of atmospheric constituents for climate analysis, the calibration stability of these measurements is expected to be within $2 \%$ and data quality is assured by manual inspection (Oltmans et al., 2006).

\section{Model description}

\subsection{Direct model}

MOCAGE is a three-dimensional CTM developed at Météo France (Peuch et al., 1999) that calculates the evolution of the atmospheric composition in accordance with dynamical, physical and chemical processes. It provides a number of configurations with different domains and grid resolutions, as well as chemical and physical parameterization packages. It can simulate the planetary boundary layer, the free troposphere, the stratosphere and a part of the mesosphere. MOCAGE is currently used for several applications: e.g., the Météo-France operational chemical weather forecasts (Dufour et al., 2005), the Monitoring Atmospheric Composition and Climate (MACC) services (http://www. gmes-atmosphere.eu), and studies about climate trends of atmospheric composition (Teyssèdre et al., 2007). It has also been validated using a large number of measurements during the Intercontinental Transport of Ozone and Precursors (ICARTT/ITOP) campaign (Bousserez et al., 2007). In this study, we used the $2^{\circ} \times 2^{\circ}$ global version of MOCAGE, with 60 sigma-hybrid vertical levels (from the surface up to $0.1 \mathrm{hPa}$ ). The transport of chemical species is based on a semi-Lagrangian advection scheme (Josse et al., 2004) and depends upon ancillary meteorological fields. The meteorological forcing fields used in our configuration are the analyses provided by the operational ECMWF numerical weather prediction model. Among the different chemical schemes available within MOCAGE, we selected for this study the linear ozone parameterization CARIOLLE (Cariolle and Teyssèdre, 2007).

The CARIOLLE scheme is based on the linearization of the ozone production/destruction rates with respect to ozone concentration, temperature and superjacent ozone column, which are precomputed using a 2D (latitude-height) chemistry model (Cariolle and Teyssèdre, 2007). Thus, it does not account for ozone production/destruction due to longitudinal and temporal variability of precursor species (e.g., $\mathrm{NO}_{\mathrm{x}}$ ), which limits the model accuracy especially in the planetary boundary layer. It includes an additional parameterization for the polar heterogeneous ozone chemistry, which allows the main features of stratospheric ozone depletion to be reproduced. It was shown that in the upper troposphere and in the lower stratosphere the linear parameterization gives satisfactory results (Cariolle and Teyssèdre, 2007) and performs well in combination with satellite data assimilation (Geer et al., 2006, 2007). An analysis of the derivatives in the CARIOLLE scheme attests that ozone production/destruction rates are quite small below $20 \mathrm{~km}$ $\left(<1 \mathrm{ppbv} \mathrm{h}^{-1}\right)$, hence the transport plays the principal role in ozone dynamics at the timescales reckoned for satellite data assimilation (12-24h). Since no tropospheric ozone removal process is modeled, a relaxation to an ozone climatology with an exponential folding time of $24 \mathrm{~h}$ is enabled in the lower troposphere, to avoid the excessive accumulation of ozone in the lowest layers during long simulations. A discussion on the consequences of the relaxation term on the assimilation are detailed in Appendix A.

\subsection{Assimilation system}

The data assimilation algorithm built around the MOCAGE model is named Valentina and was initially developed in the framework of the ASSET (Assimilation of Envisat data) project (Lahoz et al., 2007a). In its first implementation it was based on a 3D-FGAT formulation (3D-Variational in the First Guess at Appropriate Time variant; Fisher and Andersson, 2001), which was used in numerous studies on continental or global scales for the assimilation of MLS or IASI $\mathrm{O}_{3}$ data (Massart et al., 2009; El Amraoui et al., 2010; Barré et al., 2012).

In its latest version, a 4D-VAR algorithm was implemented in Valentina (Massart et al., 2012), which allows the use of longer assimilation windows in the case of nonnegligible ozone dynamics (e.g., due to strong transport) and a better exploitation of the spatiotemporal fingerprint of satellite observations (Massart et al., 2010). A 4D-VAR algorithm requires a linear tangent of the forecast model and its adjoint, which can be numerically very costly for a complete chemistry scheme. These operators have been then developed only for the transport process and for the linear ozone chemistry scheme. Assimilation windows of $12 \mathrm{~h}$ have been used in 
this study. The Valentina observation operator $(\mathbf{H})$ allows the assimilation of species concentration (e.g., vertical profiles or surface concentration), total and partial vertical columns, with the possibility to include averaging kernel information and multiple instruments at the same time. Since the model prognostic variables are the species concentration, it follows that $\mathbf{H}$ is also linear.

The background error covariance matrix (B) formulation is based on the diffusion equation approach (Weaver and Courtier, 2001) and can be specified by means of a 3D variance field (diagonal of $\mathbf{B}$, in concentration units or as a $\%$ of the background field) and a 3D field of correlation length scales.

The observation error variance (e.g., the diagonal of $\mathbf{R}$ ) can be assigned with explicit values (e.g., the pixel-based uncertainty included in some satellite products) or as $\%$ of the observation values. Only vertical error correlations are implemented in $\mathbf{R}$ in the case of profile type observations. The system provides the possibility for the adjustment of $\mathbf{B}$ and $\mathbf{R}$ diagonal terms, based on a posteriori $\chi^{2}$ statistics (Desroziers et al., 2005). For more details about the assimilation algorithm please refer to Pannekoucke and Massart (2008); Massart et al. (2009, 2012).

\section{Results and discussion}

Numerous assumptions about the statistics of the background and observation errors ( $\mathbf{B}$ and $\mathbf{R}$ matrices) are required in data assimilation algorithms (Sect. 3.2). Furthermore, the paradigm that lies behind an optimal analysis demands that the model and the observations are unbiased with respect to the unknown truth. Nevertheless, biases may contribute significantly to the overall uncertainty of both models and observations. Several methods have been proposed to take into account model or observation biases (Dee and Uppala, 2009). However, no general strategy exists when both the model and the assimilated observations are biased, which is the case encountered in this study (as detailed in Sect. 2 for the observations and by Geer et al. (2007) for the model). Hence, the validation of the analysis against independent and accurate observations remains the only way to verify the correctness of prescribed $\mathbf{B}$ and $\mathbf{R}$ matrices.

In this study ozonesonde data are used as reference to identify biases and estimate background error statistics. This approach requires that sonde profiles are unbiased and globally representative for the model, since the background error must be specified for the full model grid. Although their geographical distribution is not always homogeneous (e.g., in the Southern Hemisphere), WOUDC sondes are generally used to validate global models and satellite retrievals (Massart et al., 2009; Dufour et al., 2012).

Therefore, we proceed as follows: (i) we first run the model with/without DA for two months (August and November 2008); (ii) we compute global and monthly averages of model minus sonde values for these two months to identify biases and to assess the sensitivity of the analysis to the assimilation parameters (e.g., the background error covariance) (Sects. 4.1, 4.2, 4.3.1); (iii) a longer simulation of 6 months (with/without DA) is performed by considering eventually the outcome of (ii) and validated with additional data sets (Sect. 4.3.2).

The two months considered in (i) allow us to test the analysis during different ozone regimes (e.g., the occurrence of South Pole ozone depletion in November). Moreover, MLS and IASI analyses are first evaluated independently, to better understand the impact of the single instruments (Sects. 4.1 and 4.2), and coupled later on in Sect. 4.3.

Sonde data do not cover the upper stratosphere and assimilation parameters like error correlation length scales cannot be diagnosed using sonde-sparse data. Thereafter, we also rely upon results from previous studies, which exploited ensemble methods to estimate the error statistics for the same model and observations used in this analysis (Massart et al., 2012). Eventually, sensitivity tests will be used to assure the robustness of the analysis to the variation of the assimilation parameters (Sect. 4.3.1).

Model simulations for August 2008 and November 2008, are initialized with the MLS analysis from the study of Massart et al. (2012). This analysis is considered as a test-bed for assessing the additional benefits of IASI data assimilation. The 6 month-long simulation (Sect. 4.3.2) is instead initialized with 30 days of free model spin-up, as might be the case for an operational assimilation system, where previous analysis are not always available.

\subsection{MLS profile assimilation}

A MOCAGE-MLS ozone analysis for the entire year 2008 was examined in the study of Massart et al. (2012), with a focus on the stratosphere and on the effects of different background error parameterizations. In this section we repeat a similar analysis with particular attention to the tropopause region, which showed an enhanced bias in Massart et al. (2012) and is of greater interest for this study.

We computed the ozone field with a free run of the model (without DA, also named control run) in August/November 2008. The global average difference between this simulation and the ozonesonde profiles is displayed in Fig. 1. Differences are presented in terms of bias and RMSE components and normalized with an ozone climatological profile (Paul et al., 1998). The number and the geographical position of sonde profiles used to calculate the error statistics are also shown. A total of 182 and 167 profiles are globally available for August and November respectively, with a greater representation in the Northern Hemisphere. The error curves show that the model's free run has globally a small relative bias $(<10 \%)$ except in November inside the planetary boundary layer (PBL, $p>750 \mathrm{hPa}$ ). The good free model performance is partly due to the accurate initial conditions prescribed 
Table 1. Description of the model configuration for the assimilation experiments.

\begin{tabular}{|c|c|c|}
\hline & Type & Description \\
\hline Assimilation & 4D-VAR & $12 \mathrm{~h}$ window \\
\hline Background Error & Vertically variable (1D) & Logistic function: $30 \%$ troposphere, $5 \%$ stratosphere \\
\hline Background Error Zonal Correlation & Horizontally variable (1D) & Based on ensembles (Massart et al., 2012) \\
\hline Background Error Meridional Correl. & Constant & $300 \mathrm{~km}$ \\
\hline Background Error Vertical Correl. & Constant & 1 grid point length scale \\
\hline IASI observation error & Percentage of measurement & $15 \%$ \\
\hline MLS observation error & From retrieval product & - \\
\hline
\end{tabular}
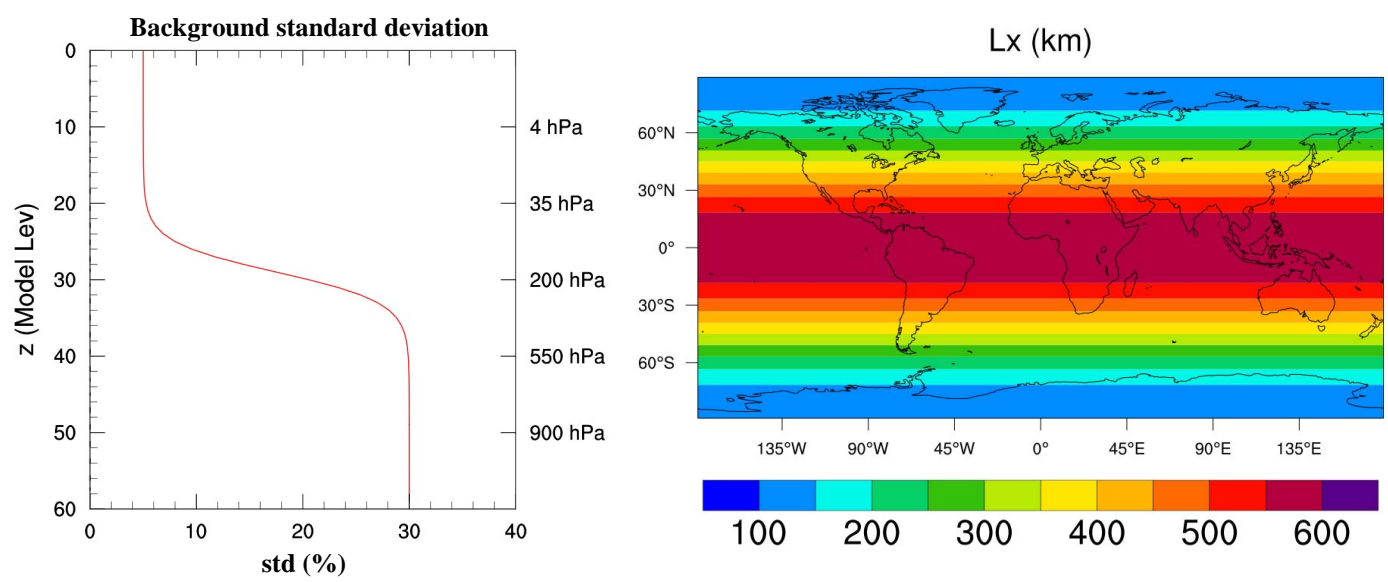

Fig. 2. Main parameterizations of the background covariance matrix (B): (left) background error standard deviation (square root of the diagonal of $\mathbf{B}$ ) in \% of the background profile; (right) zonal error correlation length scale $(L x)$. Blue/purple end colors represent values that fall outside the color scale.

on the first day of each month, which come from the previous MLS analysis. The relatively long lifetime of ozone (Sect. 3.1) implies that, assuming a good description of the transport, the model error keeps memory of those conditions for several weeks. The RMSE profile in Fig. 1 shows that below $100 \mathrm{hPa}$ the model total error increases up to about $30 \%$, with two higher peaks, one below the tropopause $(\sim 300 \mathrm{hPa})$ and the other in the PBL. Since the bias does not have such a distinct shape most of the RMSE error originates from the deficiencies of the model in reproducing the variability of measured ozone in these two layers. This behavior is not surprising in the troposphere, and especially in the PBL, since detailed ozone tropospheric chemical and physical processes are not taken into account within the $\mathrm{O}_{3}$ linearized chemistry scheme. Moreover, since the initial condition comes from MLS analysis, the model was not constrained by any observation in the troposphere. We also remark that there is no evidence of a strong monthly dependence of the error profiles.

The parameter configuration used for the assimilation experiments presented in this and in the following sections is summarized in Table 1. Compared to the study of Massart et al. (2012), the background error variance is given in percentage of the ozone field (Fig. 2) and the vertical correlation length is set to one vertical model grid point $(<700 \mathrm{~m}$ in the troposphere, $\sim 800 \mathrm{~m}$ at the tropopause and $<1.5 \mathrm{~km}$ in the stratosphere). Since the effects of using an ensemble based variance were not found to be highly significant and no estimation was available in the troposphere from the cited study, this choice was made to have a time dependent background error variance across the whole atmosphere. On the basis of the control run validation (Fig. 1), we set a bigger uncertainty in the troposphere (30\%) than in the stratosphere $(5 \%)$. The choice of a small vertical correlation length arises from the fact that IASI's averaging kernels already spread their information vertically and we do not want the contribution from the two instruments to superpose too much in a first instance. We also simplified the horizontal correlation lengths diagnosed with the ensemble of MLS perturbed analysis in Massart et al. (2012) with a zonal and time-independent average for the zonal length scale $L x$ (Fig. 2) and a constant value of $300 \mathrm{~km}$ for the meridional length scale $L y$. All these simplifications are not supposed to influence greatly the analysis, given the results in Massart et al. (2012).

The validation of the MLS analysis is also shown in Fig. 1. When all MLS levels are used (Sect. 2) both the bias and the RMSE are reduced in the stratosphere $(p<100 \mathrm{hPa})$ but 

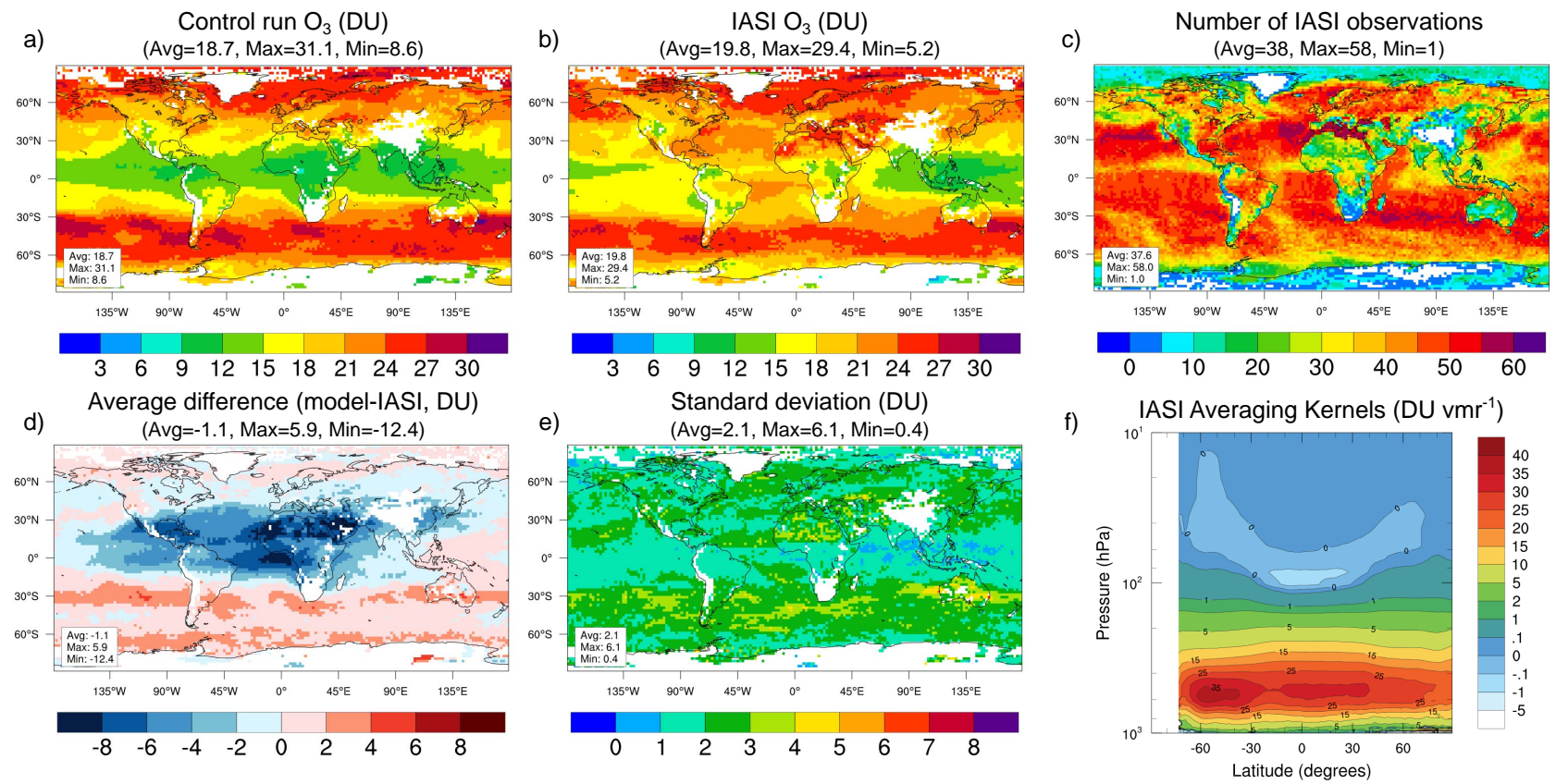

Fig. 3. Average differences between control run and IASI tropospheric columns (1000-225 hPa) for August 2008: (a) control run column weighted by IASI averaging kernels (AVK $\cdot x_{\mathrm{mod}}$, where $x_{\mathrm{mod}}$ is the model profile), (b) IASI equivalent column $\left(C_{\mathrm{obs}}-C_{\mathrm{apr}}+\mathrm{AVK} \cdot x_{\mathrm{apr}}\right.$, where $x_{\mathrm{apr}}$ is the IASI a priori profile and $C_{\mathrm{obs}}, C_{\mathrm{apr}}$ the retrieved and a priori partial columns), (c) number of IASI observations, (d) bias (model minus IASI values), (e) standard deviation of model minus IASI values, (f) IASI averaging kernels (zonal average in DU vmr ${ }^{-1}$ ). All IASI values are reduced by $10 \%$ to account for retrieval biases (Sect. 2). Blue/purple color in (a) and (b) is reserved for values lower/greater than 3/30 DU. Blue/purple color in (d) is reserved for values lower/greater than $-8 / 8$ DU. White color in (a, b, d, e) indicates pixels with a statistically insignificant number of observations $(n<10)$.

increased at around $300 \mathrm{hPa}$. This local degradation of the analysis was already observed in previous MLS assimilation studies (Stajner et al., 2008; Massart et al., 2012). Since there is strong evidence of a positive bias for the lowermost MLS level (215 hPa) (Jackson, 2007; Froidevaux et al., 2008), this level was removed from the assimilated data set, leading to a better analysis (red line in Fig. 1). The stratospheric RMSE was globally reduced to almost $10 \%$ both in August and November 2008. These results confirm the findings of a number of already cited studies that assimilated MLS ozone with other models. Note that, even after the exclusion of the $215 \mathrm{hPa}$ MLS level, the analysis ozone profile between 200 and $300 \mathrm{hPa}$ still differs slightly from the control run. Since the vertical error correlation was fixed to 1 grid point and there is approximately an 8 grid-point separation between the lowermost assimilated level $(140 \mathrm{hPa})$ and the aforementioned layer, those changes are imputable to the model dynamics, likely through downward ozone transport (STE).

\subsection{IASI tropospheric column assimilation}

IASI retrieved ozone, unlike MLS ozone, has not been used in many assimilation studies. Therefore, a comparison between observations and the correspondent free model values allows a preliminary quantification of the scatter and the systematic biases between the two. Later, the validation of the assimilated fields with independent data will provide further insights about biases with respect to "true" ozone values.

Statistics of the differences between IASI observations and the free model ozone field are reported in Figs. 3 and 4, for August and November 2008, respectively. The IASI values used to compute these figures have been reduced by $10 \%$, to compensate known retrieval biases (Sect. 2). The impact of such a bias correction on the further assimilation is detailed later in this section. IASI tropospheric partial columns (TOC, $1000-225 \mathrm{hPa}$ ) are compared to the free model equivalent columns by means of the observation operator, thus taking into account the spatiotemporal collocation and the satellite averaging kernels. Maps show that in both seasons the model significantly underestimates IASI partial columns at low latitudes $\left(30^{\circ} \mathrm{S}-30^{\circ} \mathrm{N}\right)$ in the Middle East, Africa and Central/South America (bias as high as $10 \mathrm{DU}$ (Dobson units), corresponding to $\sim 100 \%$ of model values). A smaller but positive bias $(2-4 \mathrm{DU})$ is found at lower latitudes $\left(30-90^{\circ} \mathrm{S}\right)$, which is however less significant compared to the greater local column amount. Average standard deviations are $2 \mathrm{DU}$ for both seasons with maximum values of about $5 \mathrm{DU}$ localized between $30-60^{\circ} \mathrm{S}$ and over desert regions (the Sahara and Australian deserts). 


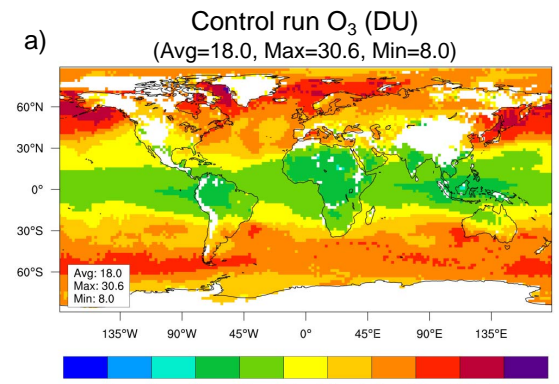

$\begin{array}{llllllllll}3 & 6 & 9 & 12 & 15 & 18 & 21 & 24 & 27 & 30\end{array}$

Average difference (model-IASI, DU)

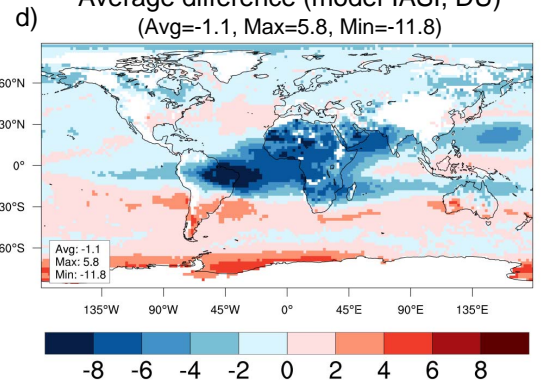

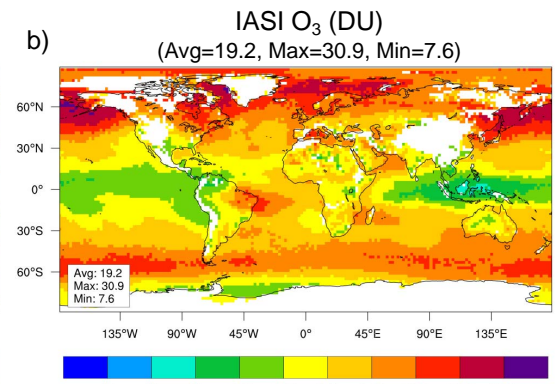

$\begin{array}{lllllllllll}3 & 6 & 9 & 12 & 15 & 18 & 21 & 24 & 27 & 30\end{array}$ Standard deviation (DU)
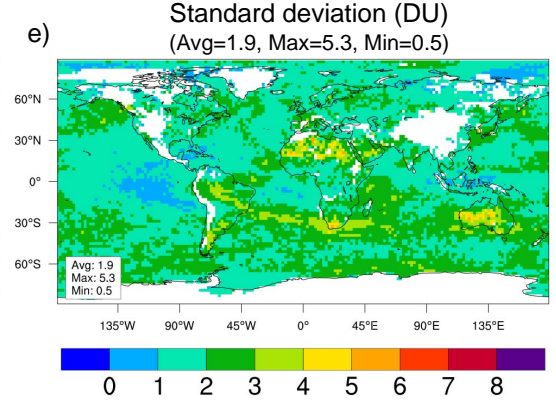

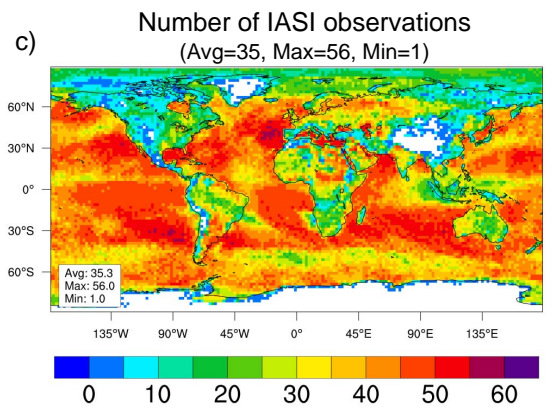

f) ${ }_{10^{1}} \mathrm{ASI}$ Averaging Kernels (DU vmr ${ }^{-1}$ )

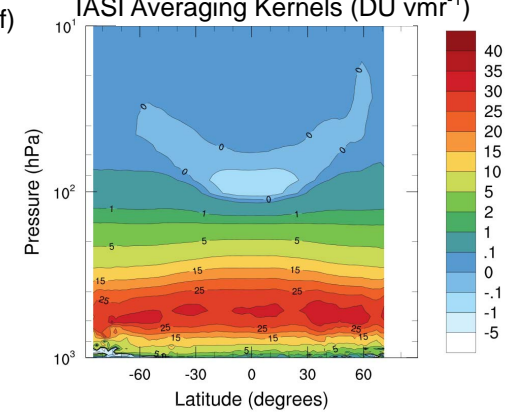

Fig. 4. Average differences between control run and IASI tropospheric columns (1000-225 hPa) for November 2008. Same plots as in Fig. 3.

High systematic differences are found in regions dominated by dust aerosols, like the Atlantic Ocean band east of the Sahara (Remer et al., 2008). Dust aerosols are known to reduce the accuracy of infrared ozone retrievals, like IASI ones. However, IASI retrievals biases for the ozone total columns are normally lower than $30 \%$ in presence of dust (Boynard et al., 2009) so that this cannot entirely explain the observed differences (as high as 100\%). Therefore the remaining systematic differences are mostly attributed to the model deficiencies. The model actually underestimates ozone in several regions affected by biomass burning outflow, like eastern Africa in August, western South America in November or in the western Indian Ocean (van der Werf et al., 2006; Barret et al., 2011). Ozone underestimation appears also well correlated with regions of high natural VOC emissions from tropical forests, such as the Amazon and the African rain forests (Guenther et al., 1995). The reason for such biases is the model simplified tropospheric chemistry, which does not take into account emissions of ozone precursors and their impact on ozone chemistry, both locally and along transport paths. This will be confirmed by the independent validation carried further in this section.

The number of monthly observations in Figs. 3 and 4 shows that IASI data enable almost a $100 \%$ coverage over oceans and, over land, more observations during the summer months than in the winter ones (August in the Northern Hemisphere and viceversa in the Southern one). This is due to the stronger thermal contrast between the atmospheric layers and the continental surface in summer, which enhances the DFS and the number of pixels that pass the AVK trace filter (Sect. 2). This is also the reason why the zonal averaging kernels (Figs. 3f, 4f), which depend mostly on the ocean-atmosphere thermal gradient, have a stronger peak during winter. Note that the screening based on the DFS value (Sect. 2.1.2) filters out most of the observations over ice and high altitude surfaces (e.g., Greenland, South Pole, Himalayas and Rocky Mountains), which have a poor thermal contrast or not enough tropospheric pressure levels available. Finally, desert regions show also a decreased number of observations due to issues in correctly representing the sand emissivity in the infrared ozone retrieval.

Figure 5 shows the error profiles for the IASI TOC analysis. The initial condition and the assimilation configuration are the same as in the MLS analysis (Sect. 4.1 and Table 1) but no MLS data are assimilated at this point. Using horizontal length scales previously diagnosed with MLS ensembles (Fig. 2) might not be pertinent for the troposphere. Nevertheless, IASI data coverage is very dense in space and time (Figs. 3,4 ) and the impact of the background error horizontal correlations is expected to be small. This will also be illustrated later in the article (Sect. 4.3.1).

When IASI data are not bias-corrected the analysis is sometimes worse than the control run (Fig. 5): the tropospheric bias increases by $10-20 \%$ for both months and the RMSE improves in August but deteriorates in November. Instead, when $10 \%$ of the values is globally removed from IASI observations the bias of the analysis improves or stays the same with respect to the control run and the RMSE is reduced by about $5-10 \%$ in both months. The profile is corrected significantly only between 200 and $800 \mathrm{hPa}$, where the AVK values are greater than $10 \mathrm{DU} \mathrm{vmr}^{-1}$ (Figs. 3 and 4). Comparing the curves in Figs. 1, 5 we conclude that with 

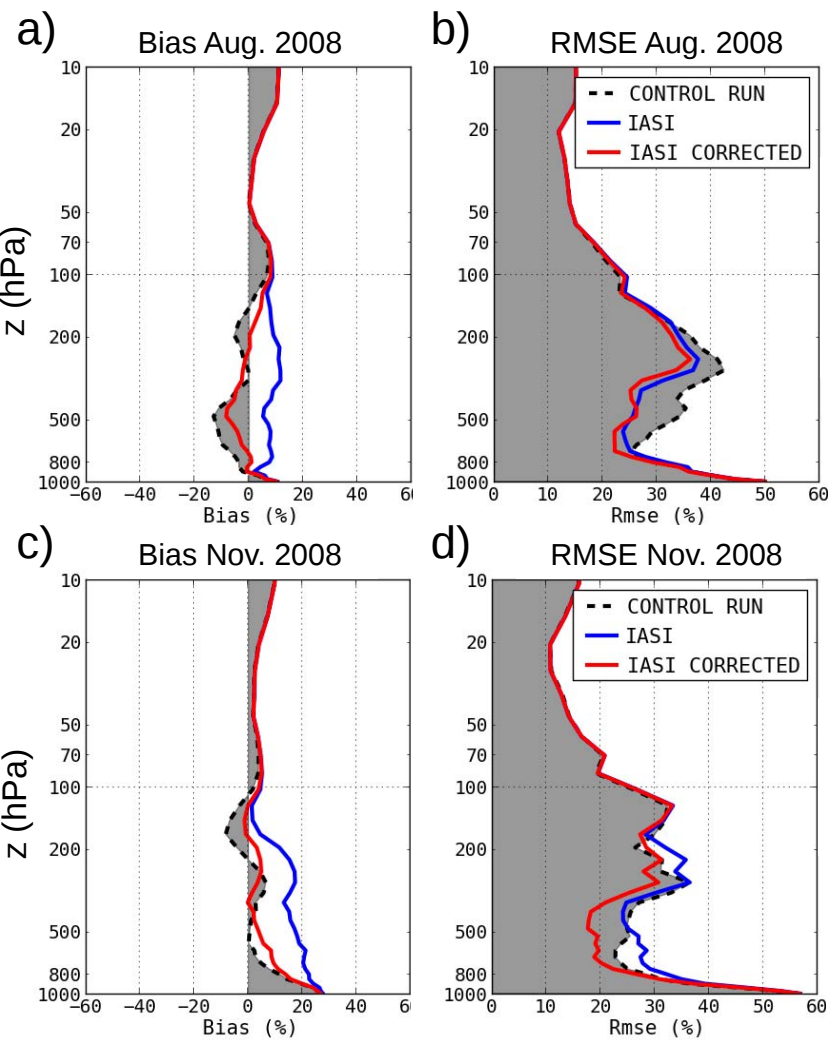

d)

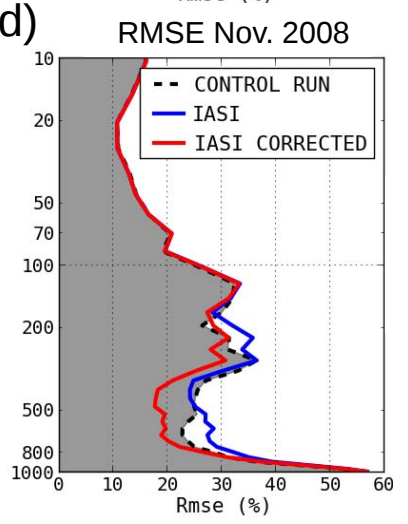

Fig. 5. Validation of control run and IASI analyses versus ozonesondes. Same plots as in Fig. 1 (August and November 2008 from top to bottom). Red curves are obtained removing $10 \%$ of the IASI ozone values before the assimilation.

the selected value of the background error vertical correlation, the correction brought by the two instruments (MLS and IASI) remains well separated vertically.

Compared with previous attempts of assimilating IASI total ozone columns in a CTM (Massart et al., 2009), we found a clear improvement in the tropospheric ozone profile. The main reason is attributed to the full exploitation of the IASI tropospheric signal in this study. Neglecting the AVK information lead to significantly worse results (not shown), which demonstrates their importance in the vertical localization of the assimilation increments. Several assimilation experiments were done with a different definition of the tropospheric column, obtained by lowering the top height of the column to 300,400 and $500 \mathrm{hPa}$. Since the AVK is spread above the specified column's top height, this was done to reduce the possible contamination of stratospheric air masses at high latitudes, which might introduce positive tropospheric ozone biases in the analysis. No significant improvements were however observed in any of these analyses.

\subsection{MLS+IASI combined assimilation}

In the previous sections MLS and IASI ozone products have been assimilated separately during August and November
2008. The purpose was to test the assimilation algorithm and detect issues like observational biases, with the help of sonde data. In this section the combined assimilation of both instruments is detailed: still for the 2 months, first separately, and for a simulation of 6 months (July-December 2008) later. In addition to the usual validation against sonde data, a comparison with OMI total ozone columns and free troposphere in situ measurements is reported. This will better clarify the added value of the IASI assimilation compared to the MLS on its own.

Figure 6 depicts the error profiles (bias and RMSE) of the combined analysis for August and November 2008 and the zonal differences between the analysis and the control run. Since the increments (differences between the analysis and the background) due to the two instruments are quite separated vertically, the error profile of the combined analysis is almost equivalent to the combination of the error profiles of the two separated analyses (Figs. 1, 5). The zonal differences (Fig. 6c, f) show that the ozone concentration is increased by $20-30 \%$ in the tropical region $\left(30^{\circ} \mathrm{S}-30^{\circ} \mathrm{N}\right)$ both in the troposphere and in the lower stratosphere, and decreased by 10$20 \%$ in the southern latitudes' $\left(30-90^{\circ} \mathrm{S}\right)$ free troposphere and at about $10 \mathrm{hPa}$. The patterns are similar in August and November, except for the northern latitudes' $\left(60-90^{\circ} \mathrm{N}\right)$ troposphere and the tropical stratosphere (in the vicinity of $10 \mathrm{hPa}$ ), where the differences for the two months have opposite signs. Moreover, the tropospheric positive increment is slightly shifted toward the northern midlatitudes in summer $\left(40^{\circ} \mathrm{N}\right)$. The average increments are able to partially compensate for the deficiencies of the direct model, which are (i) the lack of ozone precursor emissions and chemistry in the tropical/midlatitude troposphere, and (ii) the presence of high-latitude stratospheric positive biases due to a too strong poleward circulation in the forcing wind field (Cariolle and Teyssèdre, 2007; de Laat et al., 2007).

A complementary validation of the ozone fields obtained with the combined assimilation is provided by a comparison with MOZAIC data. These data allow a good geographical and temporal coverage in the Northern Hemisphere, due to the daily frequency of commercial flights, but with $90 \%$ of the data vertically confined at the airplane cruise altitude $(\sim 200 \mathrm{hPa})$. Scatter plots between model ozone values and MOZAIC observations above $400 \mathrm{hPa}$ are reported in Fig. 7. Raw data were temporally averaged on a minute basis to better fit the model's spatial resolution. Some data redundancy might still be present, even though the validation statistics are not supposed to be sensitive to that. Overall the relative error lies between 35 and $40 \%$. The scores are in agreement with those obtained using sonde data (cf. Fig. 6, at $200 \mathrm{hPa}$ level) and confirm a modest improvement of the correlation and the RMSE for the IASI+MLS analysis in August and a slight worsening in November. Since the validation with sonde and aircraft data shows a good agreement but sondes have a better global and vertical coverage (cf. Fig. 1), only sonde validation will be shown hereafter. 

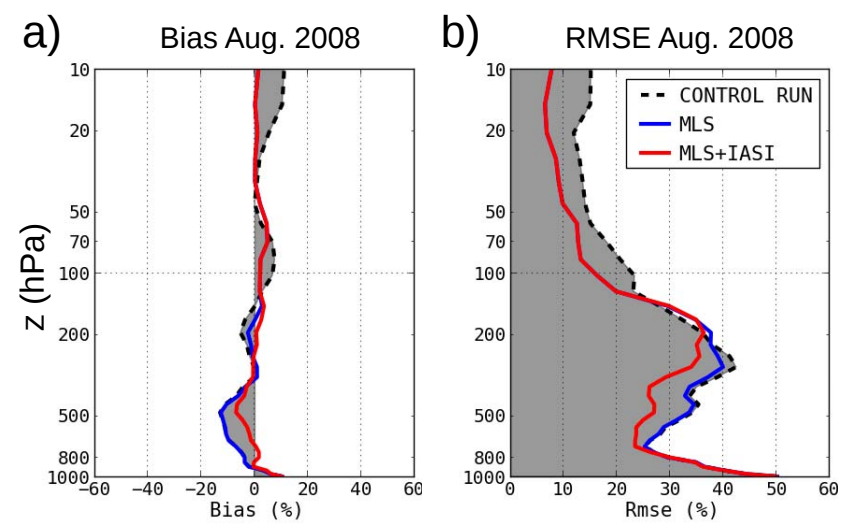

C) MLS+IASI analysis minus control run $\mathrm{O}_{3}(\%)$
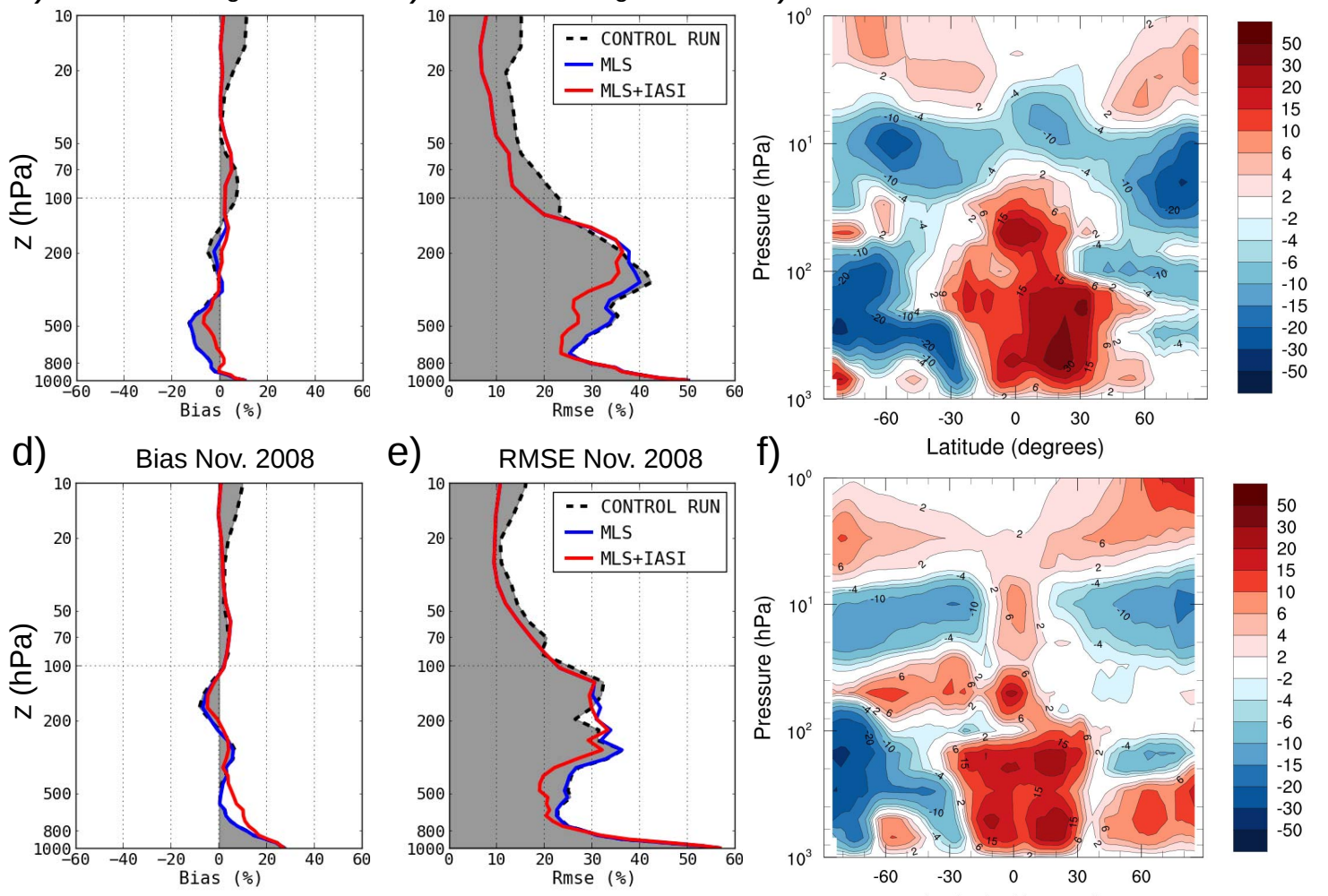

e)
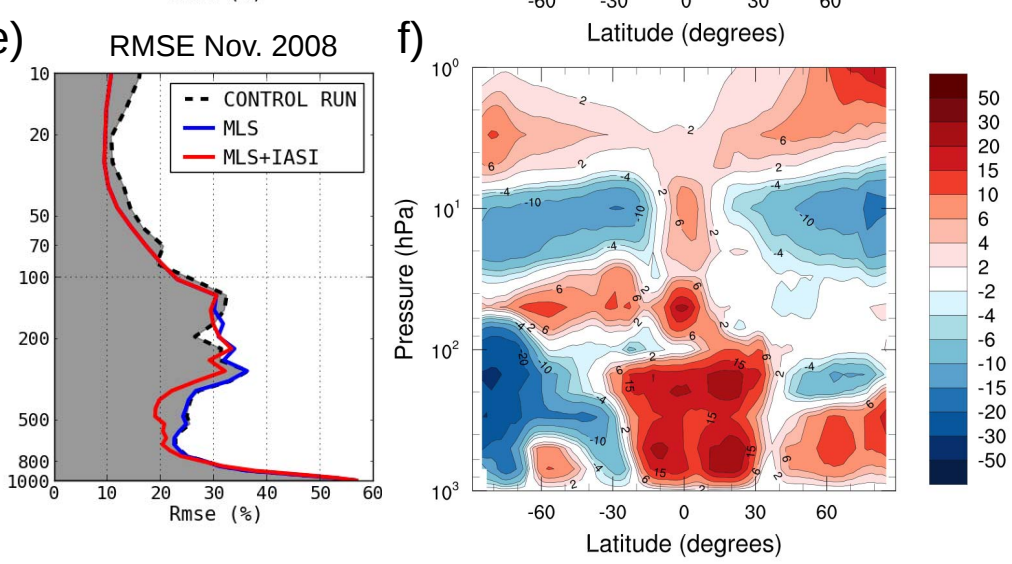

Fig. 6. Validation of control run, MLS analysis and combined IASI+MLS analysis versus ozonesondes. (a, b, d, e) same plots as in Fig. 1 (August and November 2008 from top to bottom), (c, f) average zonal difference between control run and IASI+MLS analysis normalized with climatology. Dark blue/red color in (c) and (f) is reserved for values lower/greater than $-50 / 50 \%$.

Figure 8 shows the geographical differences of the tropospheric ozone column between the control run and the analysis. In addition to Fig. 6, which already highlighted the zonal features of the increments, we note a significant increase of the TOC over the African continent and the Atlantic region, whereas the local ozone minimum over Indonesia is not changed or even slightly decreased. This is consistent with the preliminary comparison between modeled and IASI ozone shown in Figs. 3 and 4. The main spatial features of the analysis in the tropics are well comparable with the satellite climatology of TOC derived by Ziemke et al. (2011). Differences between the two data sets depend not only on the methodology and the measurements being used, but also on the definition of the tropospheric column $(1000-225 \mathrm{hPa}$ in this study, surface-dynamical tropopause in Ziemke et al., 2011). Hence, a more quantitative comparison would require the same definition of the tropospheric column to be adopted.

A quantitative comparison of the analysis with OMI total ozone columns is presented in Fig. 9. The comparison is done between independent averages of both data sets, which do not consider the exact temporal matching. Since OMI permits a daily global coverage, differences due to this reason are assumed negligible. The greatest positive correction orig- inates from the assimilation of MLS data, which modifies the more abundant stratospheric ozone. However, the addition of IASI TOC permits reaching the best agreement between the analysis and OMI data in the tropics, where the stratospheric column amount is lower and the total ozone column is more sensitive to the tropospheric amount.

\subsubsection{Sensitivity of the analysis to the background/ observation error covariance}

Before calculating the 6 month-long analysis, alternative formulations of the background and the observation error covariance matrices were tested to verify the robustness of the analysis to the choice of the assimilation parameters. The following cases were considered, where the nonspecified parameters are kept as in Table 1:

- temporally constant background variance expressed in ozone concentration units and derived from the MLS ensemble (Massart et al., 2012) above the tropopause (full 3D field) and from sonde validation in the troposphere (zonally averaged field, three latitude bands used); 

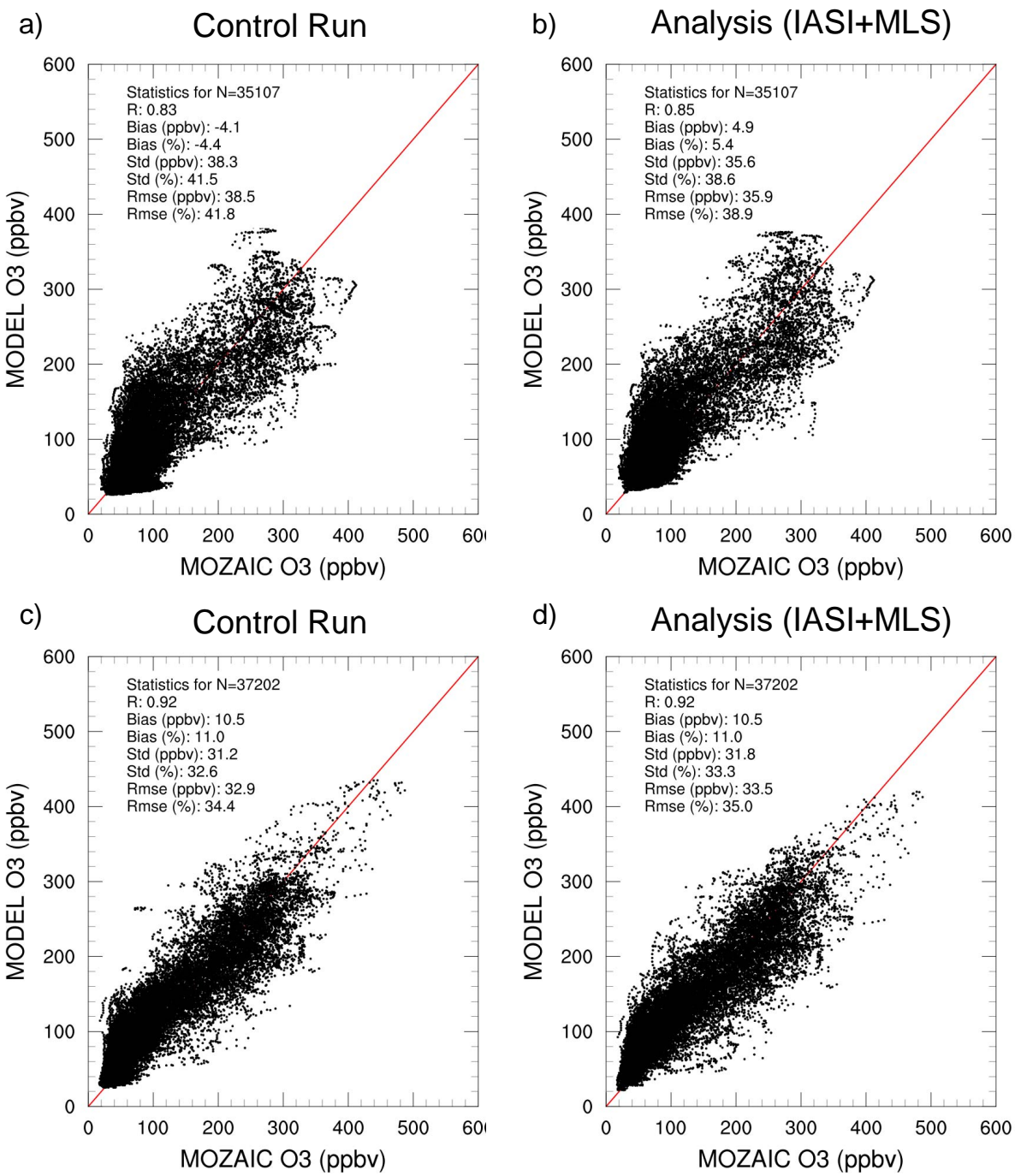

Fig. 7. Validation of model ozone values versus MOZAIC observations above $400 \mathrm{hPa}$ (a) scatter plot between control run and MOZAIC values for August 2008 (b) scatter plot between IASI+MLS analysis and MOZAIC values for August 2008, (c, d) same as (a, b) but for November 2008. Difference statistics are displayed in each plot in terms of number of points $(N)$, correlation $(R)$, bias in ppbv (modelmeasurements), relative bias (bias/measurements average), standard deviation in ppbv (Std), relative standard deviation (Std/measurements average), RMSE in ppbv and relative RMSE (RMSE/measurements average).

- background variance equal to $20 \%$ of the ozone field everywhere, constant and homogenous horizontal error length scale equal to $4^{\circ}$ in both horizontal directions;

- error statistics as in Table 1 but optimization of $\mathbf{B}$ and $\mathbf{R}$ matrixes based on a posteriori diagnostics (Sect. 3.2).

The first two represent two cases of a more/less detailed $\mathbf{B}$ matrix and the last one a case of statistical optimization of $\mathbf{B}$ and $\mathbf{R}$ at the same time. Additional possibilities exist: for example the verification of the MLS+IASI 4D-VAR background against sonde data can be further used to update $\mathbf{B}$ and recompute a new analysis. However, this method was not tested in the framework of this study. In all examined cases the comparison with sonde profiles was not found to be superior or differences with the reference analysis were not significant (not shown). The reasons are attributed to the combination of the high temporal frequency of the assimilated satellite observations and the relatively slow ozone chemistry, which makes the background error strongly dependent on the initial condition. Once the model is corrected for the inexact initial conditions, further assimilation increments only bring minor adjustments, which keep the model close to the temporal trajectory of observations. This can be better clarified looking at the observation minus forecast $(\mathrm{OmF})$ global statistics during the initial period of data assimilation in the case of the long-run experiment (Fig. 10). 

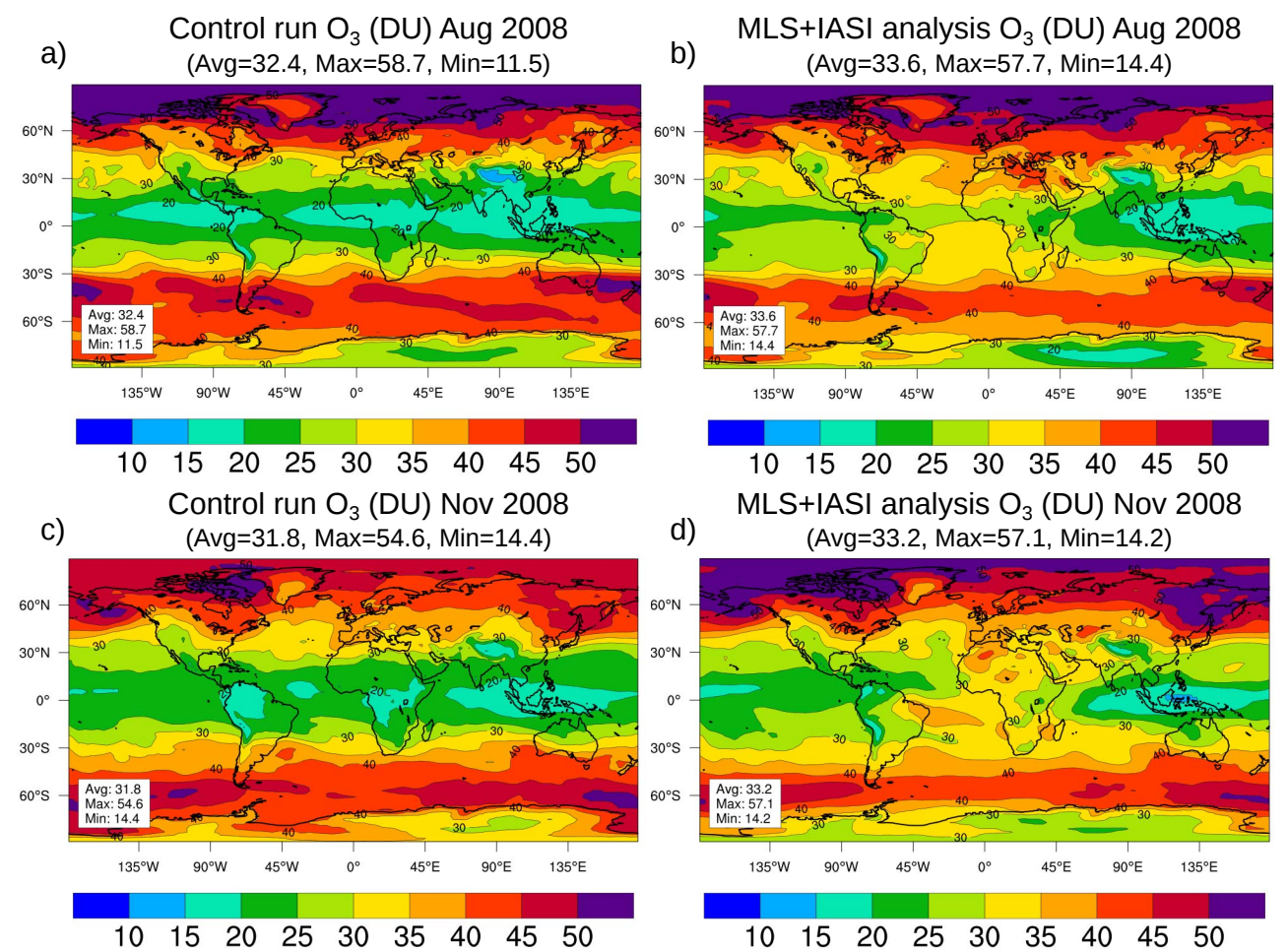

Fig. 8. Ozone tropospheric columns (1000-225 hPa): (a) control run for August 2008, (b) MLS+IASI analysis for August 2008, (c) control run for November 2008, (d) MLS+IASI analysis for November 2008. Blue/purple color is reserved for values lower/greater than 10/50 DU.

The initial condition is not issued from a previous MLS analysis in this case but comes from a 30 day model spin-up period. It follows that, compared to the case of the simulations for August and November 2008, the model field differs initially more from the observations, especially the MLS ones. It takes approximately 3 days (6 assimilation windows) to reach the forecast-model minimum for both the $\mathrm{OmF}$ average and standard deviation. The model forecast at $10 \mathrm{hPa}$, which is initially biased high by $1000 \mathrm{ppbv}$ and has a standard deviation of $400 \mathrm{ppbv}$ with respect to MLS measurements, reduces its bias to $100 \mathrm{ppbv}$ and its scatter to $200 \mathrm{ppbv}$ after 4 assimilation windows $(48 \mathrm{~h})$. In the case of IASI the bias and the scatter are reduced just after $24 \mathrm{~h}$ to $\sim 0 \mathrm{DU}$ for the bias and 1.5-2 DU for the standard deviation from an initial value of 2 and $3 \mathrm{DU}$, respectively. Subsequent values of OmF are of the order of the prescribed observation errors, which are about 200-300 ppbv for MLS $10 \mathrm{hPa}$ level (Froidevaux et al., 2008) or $15 \%$ of IASI TOC columns (Fig. 3), so that a further reduction is not possible. Note that IASI observations cover $80 \%$ of the horizontal grid after $48 \mathrm{~h}$, whereas MLS attains $40 \%$ after $72 \mathrm{~h}$ (Fig. 10c). This explains the faster convergence of IASI OmF statistics. In other words, observations are dense enough to well constrain the longterm ( $>5$ days) temporal evolution of the model, regardless of significant variations of the background covariance matrix. Different choices of the background covariance may de- termine the rapidity of the convergence during the initial assimilation windows.

\subsubsection{Validation of the 6 month-long simulations}

The 6 month-long assimilation experiment (analysis) is initialized with a free model spin-up of 1 month in June 2008. The assimilation starts on 1 July 2008 and ends on 31 December 2008. For the same period a simulation without data assimilation (control run) is calculated.

Figure 11 shows the Taylor diagram of the collocated model-sonde columns. The 6 month period allows to accumulate enough sonde profiles to validate the model separately for different latitude bands. In addition to the tropospheric column (TOC, 1000-225 hPa), also the UTLS (225$70 \mathrm{hPa}$ ) column is considered. This type of plot depicts the capacity of the model to explain the variability of the validation data set. In Figs. 12 and 13 columns/profiles bias, RMSE and standard deviation are also displayed to give a complete picture of the model performance. The results can be summarized as follows:

- globally the UTLS column scores are significantly better for the analysis $(R=0.98$, bias $<1 \%$, RMSE $\sim 15 \%)$ than for the control run $(R=0.9$, bias $\sim 15 \%$, RMSE $\sim 30 \%$ ); 

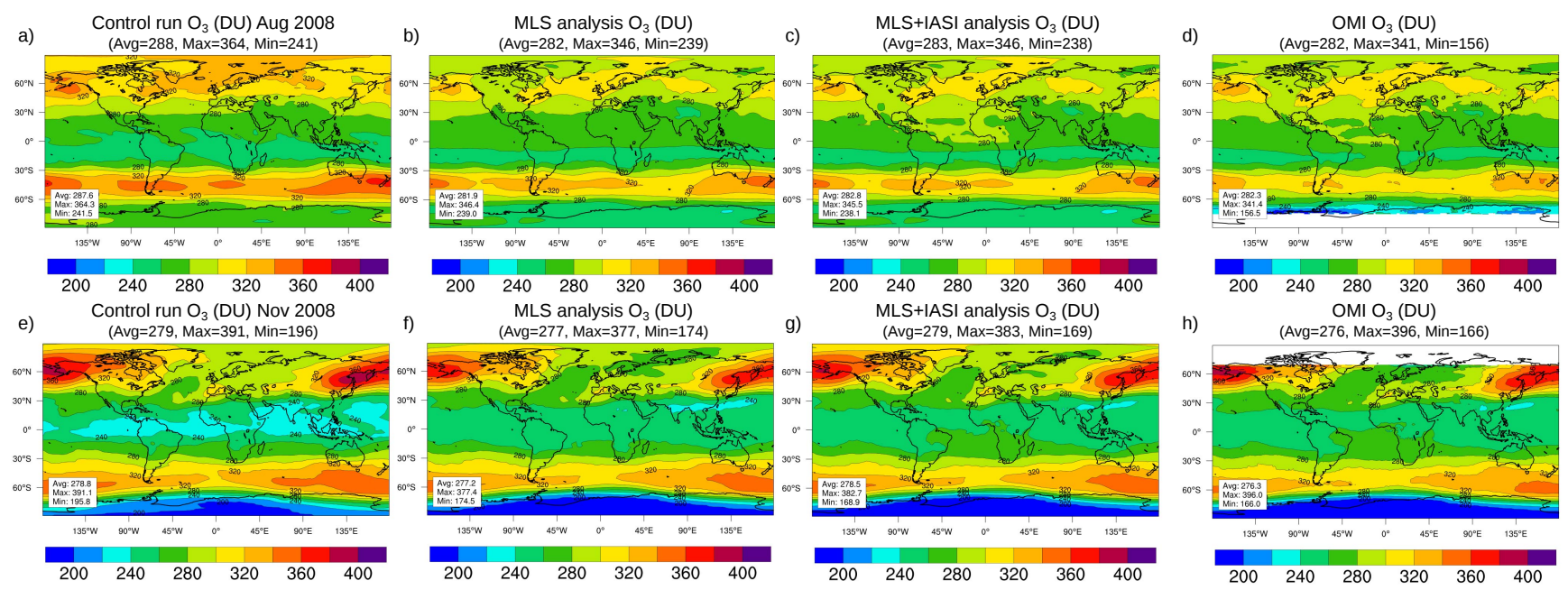

Fig. 9. Validation of model total ozone columns versus OMI measurements: (a) control run average ozone column for August 2008, (b) MLS analysis for August 2008, (c) MLS+IASI analysis for August 2008, (d) OMI measurements for August 2008, (e, f, g, h) the same plots but for November 2008. Blue/purple color is reserved for values lower/greater than 200/400 DU. White color in (d, h) indicates pixels without OMI observations.

- the control run shows in particular a very high UTLS error in the $90-60^{\circ} \mathrm{S}$ band (bias $\sim 50 \%$, RMSE 60\%), due to the linear chemistry limitations with regards to the mechanism of ozone depletion;

- the tropospheric column scores are also globally better for the analysis $(R=0.7$, bias $<5 \%$ in magnitude, RMSE $\sim 20 \%)$ than for the control run $(R=0.6$, bias $\sim-10 \%$, RMSE $~ 25 \%$ ), even though to a lesser extent than in the case of the UTLS layer;

- all analysis tropospheric scores are significantly better than those of the control run at the tropics, but only the bias is substantially improved at northern midlatitudes (bias from -15 to $<5 \%$ );

- in the $30-60^{\circ} \mathrm{S}$ and $60-90^{\circ} \mathrm{N}$ bands the tropospheric bias of the analysis field increases with respect to the control run. It follows that the analysis RMSEs are not improved and the Taylor diagram scores are unchanged or even deteriorated;

- the analysis TOC is particularly inaccurate in the $90-60^{\circ} \mathrm{S}$ band $(R=0.3$, bias $\sim 20 \%$, RMSE $\sim 25 \%$ ). However, the control run has already poor skills and very few IASI observations are assimilated during the whole period (Figs. 3, 4).

The good quality of the UTLS ozone analysis with MLS data confirm the findings of previous studies (Jackson, 2007; El Amraoui et al., 2010; Massart et al., 2012). The results appear more heterogeneous with regards to the tropospheric analysis. The MLS+IASI assimilation has a robust and positive impact at low latitudes $\left(30^{\circ} \mathrm{S}-30^{\circ} \mathrm{N}\right)$ which, however, becomes less evident at high latitudes and in polar regions.
Other studies also identified difficulties in improving modeled tropospheric column at high latitudes by means of satellite data assimilation (Lamarque et al., 2002; Stajner et al., 2008). With respect to the studies of Barré et al. (2013) and Coman et al. (2012) on the European domain, we found similar conclusions about the capacity of IASI to reduce the model free-troposphere bias at northern midlatitudes (30$60^{\circ} \mathrm{N}$ ). However, it is found that IASI was not able to improve the model variability (standard deviation) in this region. We conclude that IASI measurements, even if directly sensitive to the tropospheric ozone concentration, are not able to fill this gap. Since modeled TOC at high latitudes is quite accurate (RMSE 20\%, Fig. 12), we assume that IASI retrieval biases become too large compared to model errors. Besides, the $10 \%$ bias removed globally from IASI columns could have a zonal dependence, which was not considered in this study. However, additional validation studies of IASI products would be required to quantify tropospheric retrieval errors at high latitudes.

Sonde data provide accurate information about the ozone vertical profile but their measurement frequency does not allow a daily- or hourly-scale validation of model predictions. Therefore, hourly measurements from two in situ stations located above $3000 \mathrm{~m}$ are used to verify the free-troposphere ozone dynamics of the models. The two selected sites are at the tropics (Mauna Loa, $19.54^{\circ} \mathrm{N}, 155.58^{\circ} \mathrm{W}$ ) and at high latitudes (Summit, $75.58^{\circ} \mathrm{N}, 38.48^{\circ} \mathrm{W}$ ). Figure 14 shows the time series of the analysis, the control run and the correspondent observations in August and November 2008. Since the ozone variability at very small spatial and temporal scales cannot be captured by a $2^{\circ} \times 2^{\circ}$ grid model, original hourly observations have been smoothed in time using a moving average of $\pm 6 \mathrm{~h}$. This allows us to enhance the ozone 

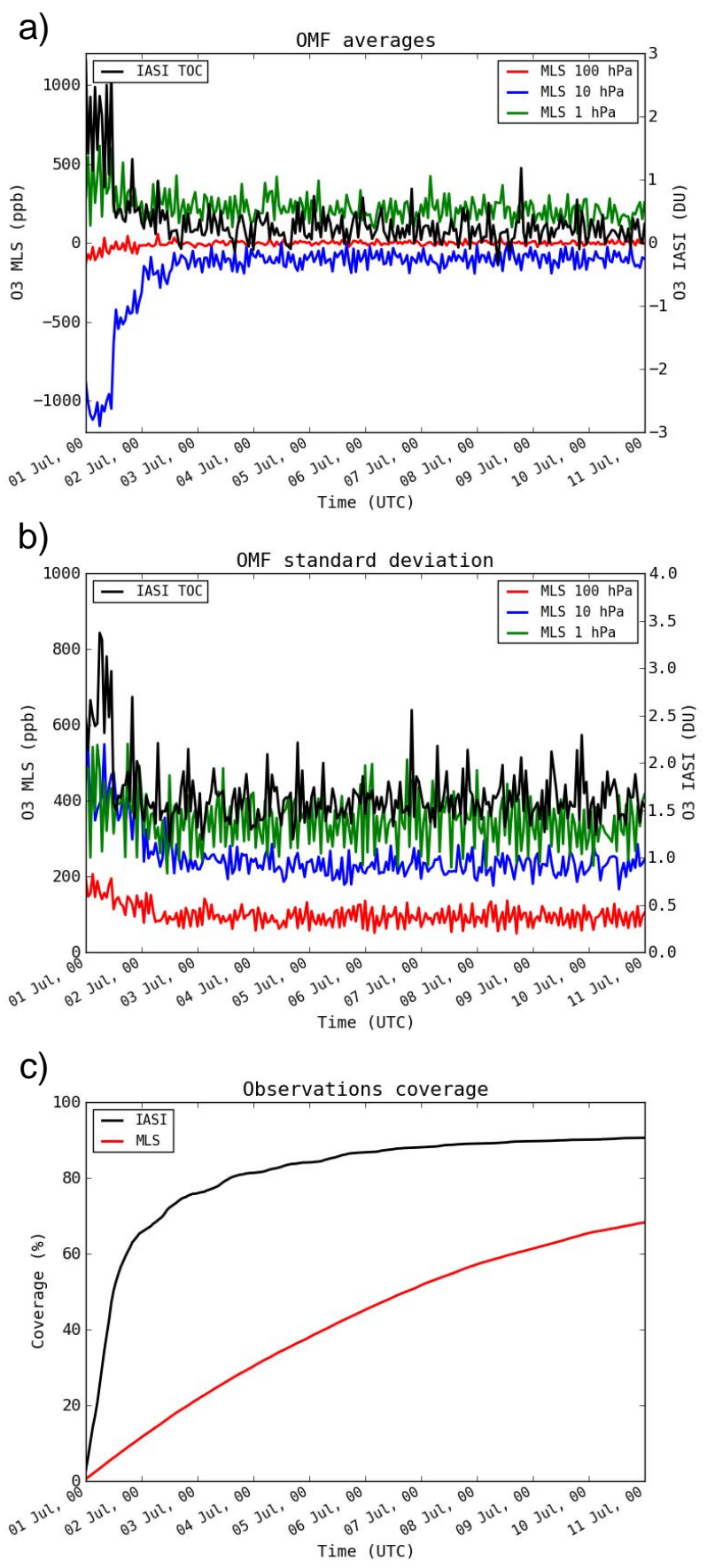

Fig. 10. Observation minus Forecast $(\mathrm{OmF})$ statistics for the first 10 days of the IASI+MLS long analysis (1-10 July 2008). Assimilated observations minus their model equivalent values are averaged globally for each hour. (a) OmF average, (b) OmF standard deviation, (c) temporal evolution of the observation's global coverage (fraction of model horizontal grid pixels visited by the satellite). IASI's tropospheric columns minus their model equivalent (as in Fig. 3) are represented with a black line. MLS observations minus their model equivalent with red $(100 \mathrm{hPa}$ level $)$, blue $(10 \mathrm{hPa})$ and green $(1 \mathrm{hPa})$ line respectively. variability signal due to transport that the model is supposed to reproduce.

The control run underestimates the temporal variability of observations, as expected from a model that does not account for tropospheric chemistry. The analysis field has an increased variability when compared to the control one, still maintaining its low bias in magnitude. However, the scores in term of correlation and standard deviation between the analysis time series and the observations (not shown) are not necessarily better than those of the control run. In particular, the occurrence of ozone minima ( $\sim 20 \mathrm{ppbv}$ ) lasting more than 2-3 days in the Mauna Loa time series is mostly due to the transport of low-ozone air masses from the equatorial boundary layer (below $700 \mathrm{hPa}$ ). The duration of these episodes is well captured by the control run but their amplitude is not, and IASI's low sensitivity to the lower vertical layers does not permit to account for it. Note that at the Summit site and during August, the analysis is almost coincident with the control run because there are very few observations being assimilated in the surroundings (Fig. 3c).

This comparison leads to the conclusion that the assimilation of column integrated information corrects well the model tropospheric column (e.g., at the tropics, Figs. 12 and 11) but does not necessarily improve the model prediction at a single vertical level. IASI AVKs redistribute the satellite information in accordance with their vertical sensitivity and their a priori, but the increments inside the partial column are still assigned proportionally to the model background profile. Hence, model predictions at a single vertical level do not necessarily ensure the same accuracy as the one found for partial columns.

\section{Conclusions}

In this study we examined the impact of MLS and IASI (SOFRID product) ozone measurements to constrain the ozone field of a global CTM (MOCAGE) by means of variational data assimilation and with particular emphasis on tropospheric ozone. Given the ozone average lifetime of several weeks in the free troposphere, the high spatial coverage of IASI data is able to make up for the deficiencies of the linear chemistry model used.

Results confirm the effectiveness of MLS profiles assimilation in the stratosphere, with an average reduction of RMSE with respect to ozonesondes from 30 (control run) to $15 \%$ (analysis) for the UTLS column. The lowermost level of MLS ozone data $(215 \mathrm{hPa})$ was found to increase the analysis bias in the troposphere and is not further used. Improvements of the TOC due to IASI $\mathrm{O}_{3}$ data assimilation depend on the latitude and highlight the need to properly account for retrieval biases. When a globally constant $10 \%$ positive bias is removed from IASI observations, the TOC RMSE decreases from 40 (control run) to $20 \%$ (analysis) in the tropics and from 22 to $17 \%$ in the Northern Hemisphere $\left(30-60^{\circ} \mathrm{N}\right)$ 

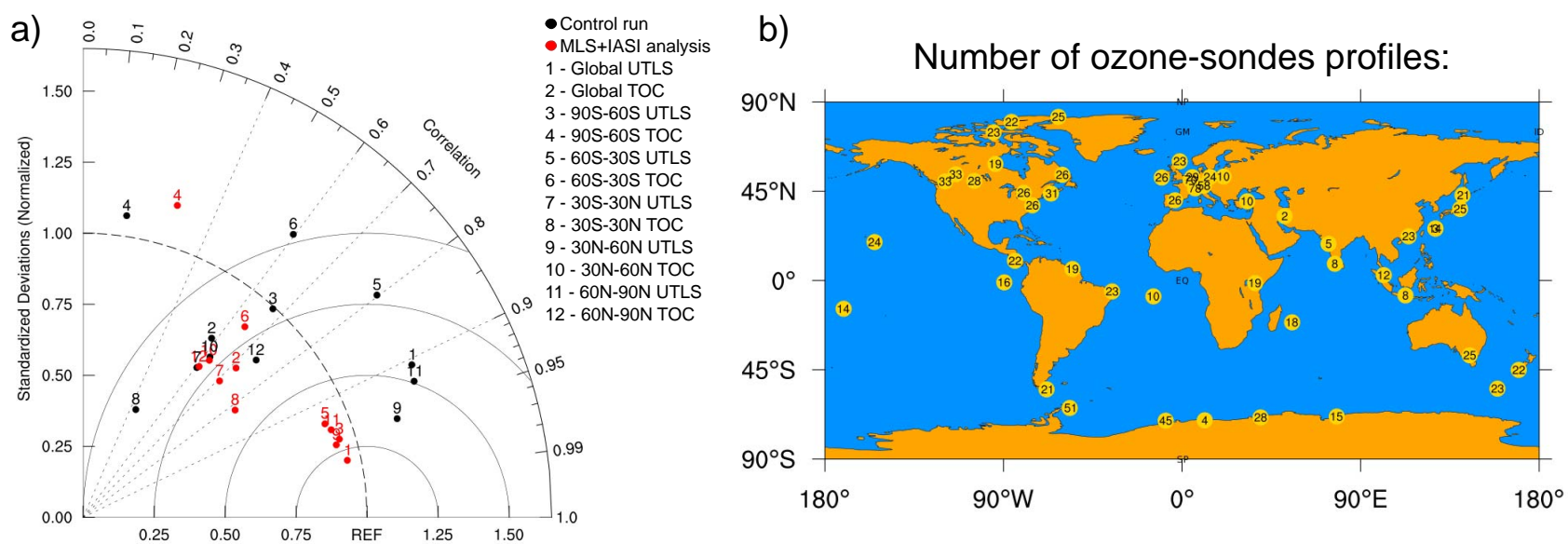

Fig. 11. Global and zonal validation of MLS+IASI analysis partial columns (1000-225 hPa as TOC and 225-70 hPa as UTLS) versus ozonesondes for the long analysis run (July-December 2008); (a) Taylor diagram (control run in black, analysis in red) and (b) number of used ozonesonde profiles.
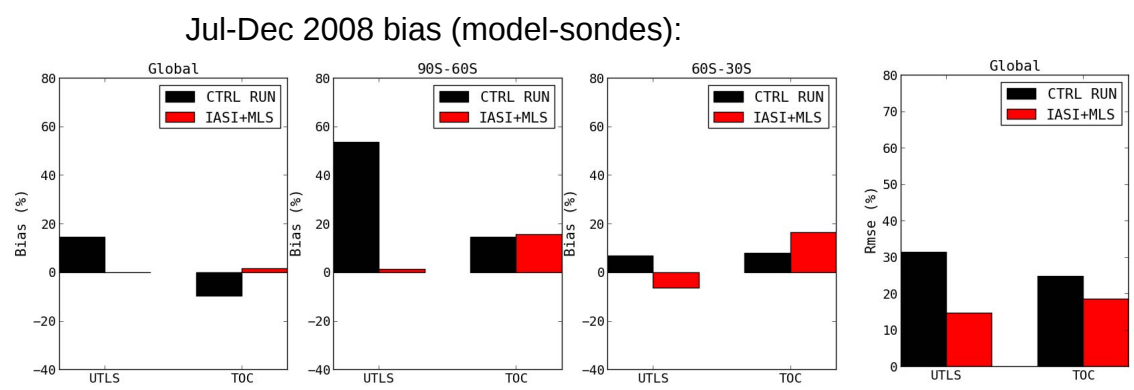

Jul-Dec 2008 RMSE:
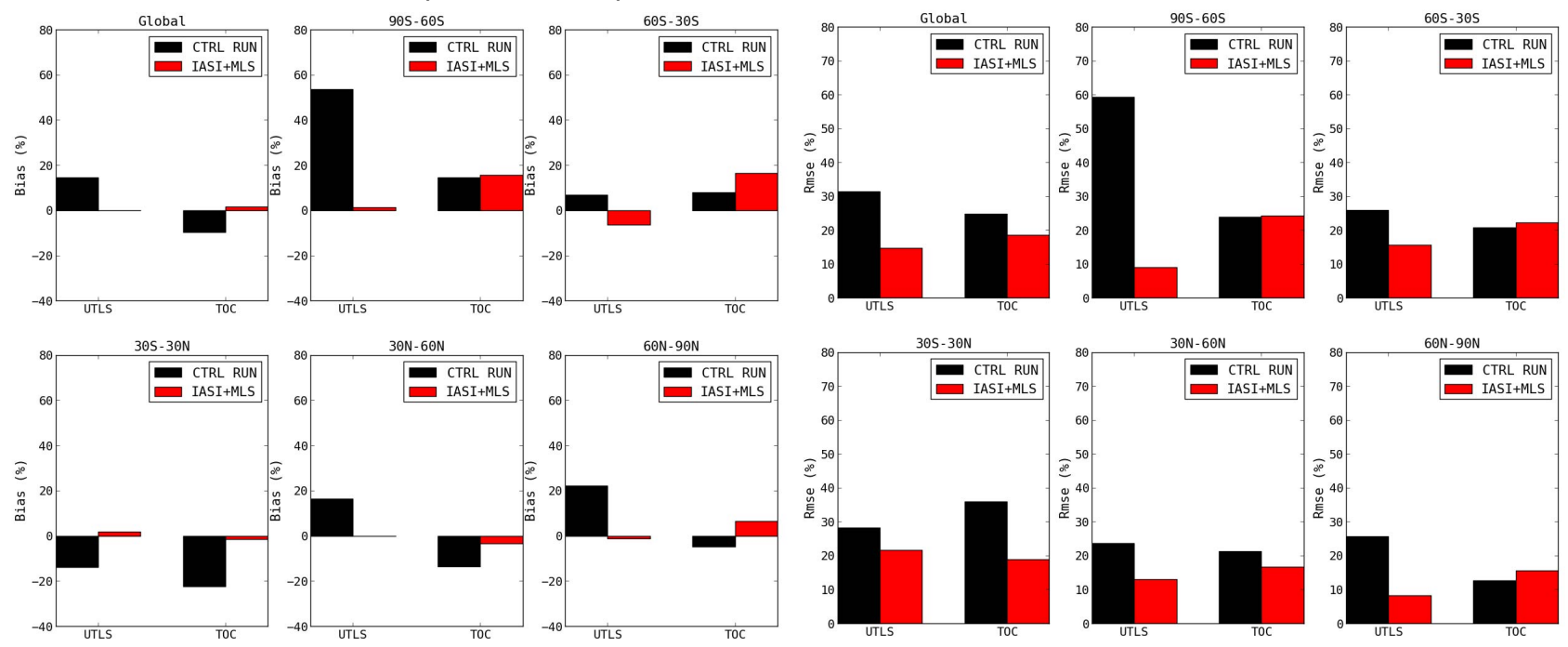

Fig. 12. Global and zonal validation of MLS+IASI analysis partial columns (1000-225 hPa as TOC and 225-70 hPa as UTLS) versus ozonesondes for the long analysis run (July-December 2008). Leftmost 6 panels: bias (model sondes) normalized with the climatology (control run in black, analysis in red). Rightmost 6 panels: RMSE normalized with the climatology.

whereas it slightly increases (1-2\%) at other latitudes, probably due to residual IASI biases. Overall, the combined assimilation of MLS and IASI improves the correlations with ozonesonde data for both the UTLS and TOC columns at almost all latitudes and increases the agreement with OMI total ozone column measurements. It is also found that the analysis is not very sensitive to the parameterization of the background error covariance, due to the high temporal frequency of IASI and MLS observations and the strong dependency of the ozone field on the initial condition. Finally a comparison with hourly-resolved in situ measurements in the free troposphere shows that assimilating information with a coarse ver- tical resolution increases the model variability but does not ensure a better hourly analysis at a particular vertical level.

We conclude that the assimilation of IASI and MLS data is very beneficial in combination with a linear ozone chemistry scheme. The high frequency of IASI observations is able to partially compensate for the model simplified tropospheric chemistry, especially at low latitudes and also in regions affected by strong seasonal emissions of ozone precursors (e.g., biomass burnings). Such an assimilation strategy provides reliable tropospheric and stratospheric ozone fields and might be valuable for near-real-time operational services and as benchmark for more sophisticated CTMs. Limitations concern surface ozone, where IASI's low sensitivity cannot 
Jul-Dec 2008 bias (model-sondes):
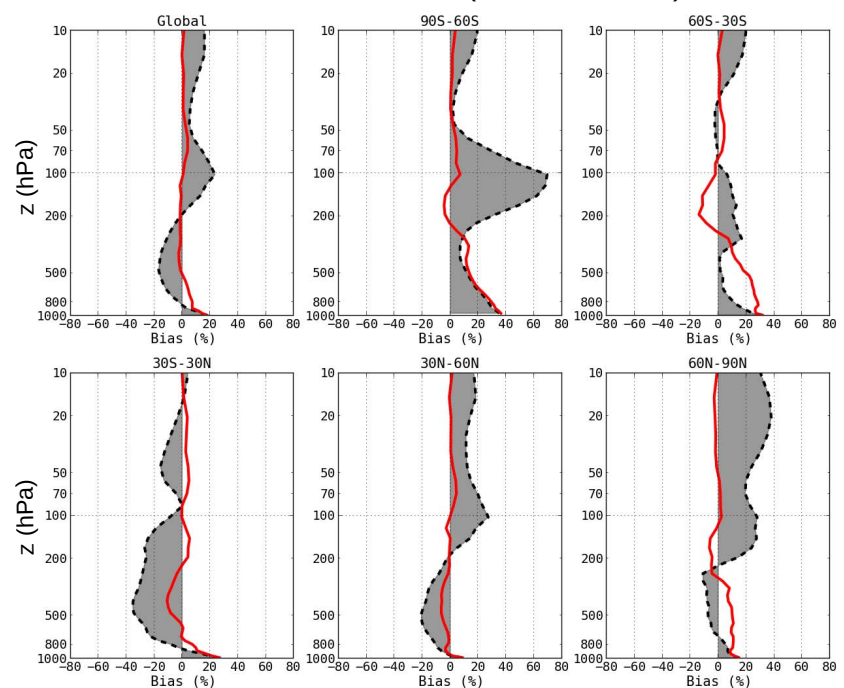

Jul-Dec 2008 standard deviation:
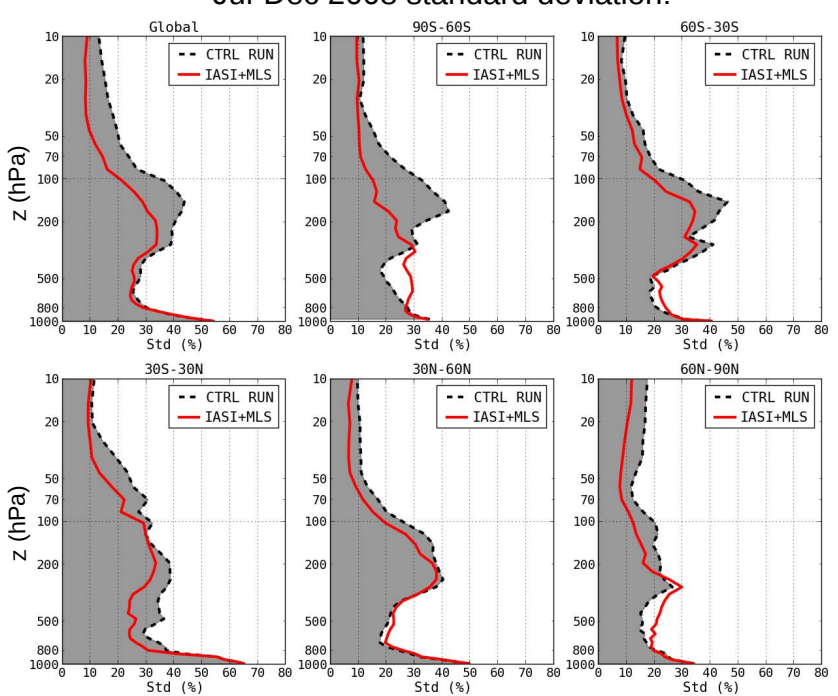

Fig. 13. Global and zonal validation of MLS+IASI analysis versus ozonesonde profiles for the long analysis run (July-December 2008). Leftmost 6 panels: bias (model minus sondes) normalized with the climatology (control run in black, analysis in red). Rightmost 6 panels: standard deviation normalized with the climatology.
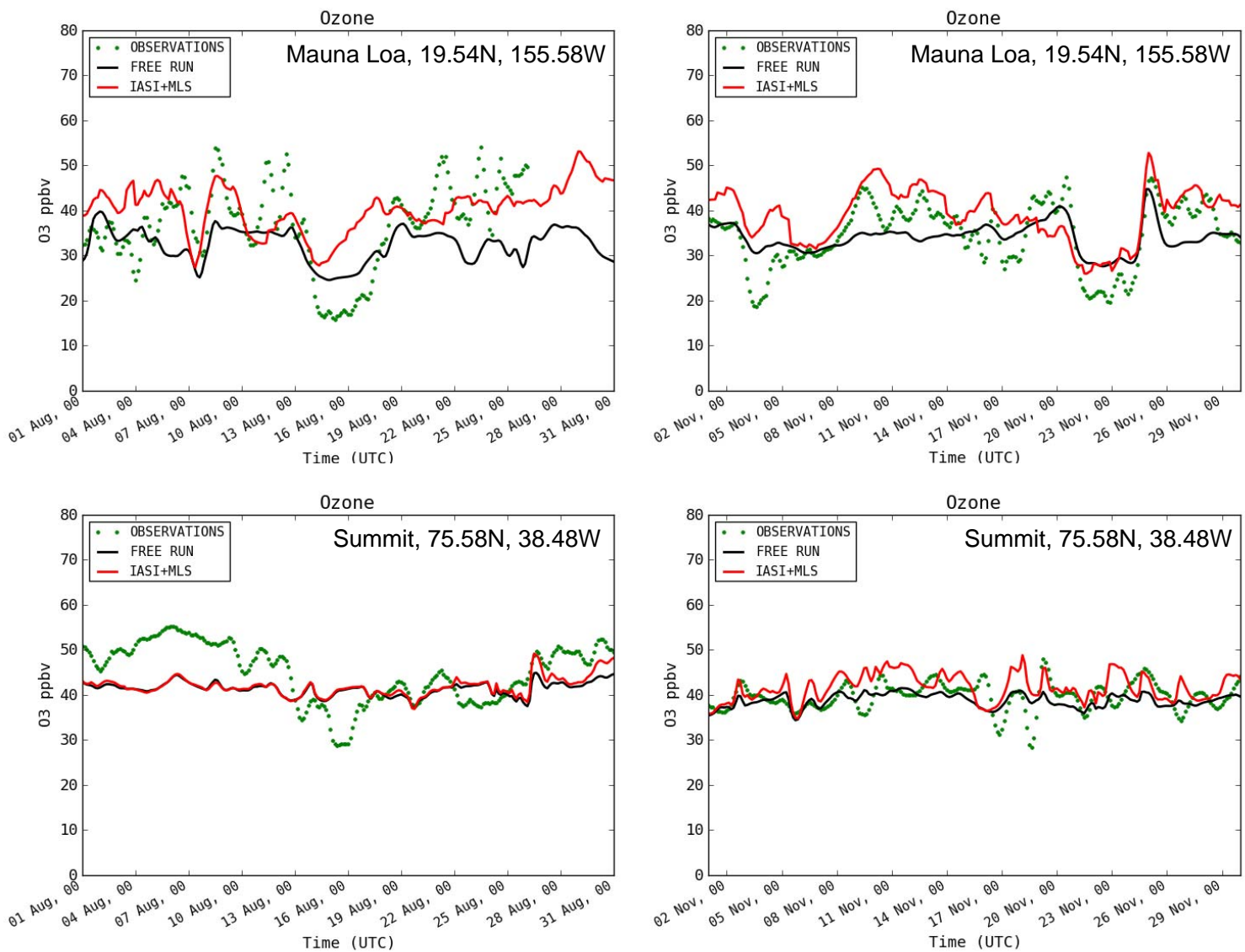

Fig. 14. Time series of hourly measured ozone mixing ratio (green dots) at the sites of Mauna Loa (MLO, $19.54^{\circ} \mathrm{N}, 155.58^{\circ} \mathrm{W}, 3397 \mathrm{~m}$ a.s.1., US) and Summit (SUM, 75.58 N, 38.48 ${ }^{\circ} \mathrm{W}, 3216 \mathrm{~m}$ a.s.1., Greenland) in August/November 2008 and correspondent model predictions: control run (black line), IASI+MLS analysis (red line). 
directly make up for missing ozone precursors emissions and chemistry. However, IASI's assimilation remains effective when the focus is on the free troposphere. Future applications of this system are the evaluation of tropopause ozone flux, a multi-annual climatology of global tropospheric ozone, analysis of major pollution episodes and prescription of chemical boundary conditions for regional models. Possible improvements of the IASI analysis might be obtained by assimilating IASI radiances directly into the CTM, thus considering a dynamical a priori profile in the radiance inversion, instead of one issued from a climatology. Moreover, the development of a 4D-VAR assimilation chain for the complete chemistry model will allow in future to consider the feedbacks of satellite ozone assimilation on other species.

\section{Appendix A}

\section{On the influence of the ozone climatological relaxation}

A linear ozone chemistry scheme has been employed in this study (Sect. 3). The main drawback of this scheme is that the modeling of tropospheric ozone sources, sinks and chemistry is missing. These processes are replaced by a relaxation to a zonal climatology to avoid tropospheric ozone accumulation due to the vertical transport during long simulations. This appendix clarifies the deficiencies of the climatological relaxation within the adopted data assimilation framework. For example, the climatological relaxation counteracts the assimilation increments and might lessen the adjustments produced by observations.

A model simulation has been initialized on 5 July 2008 at 00:00 UTC using the ozone field calculated from the 6 month analysis (Sect. 4.3.2). On this date the ozone field has been well constrained by the observations assimilated during the previous days (Fig. 10) and it represents an initial condition quite different from the model climatology. Starting from this initial condition, a free model simulation of $24 \mathrm{~h}$ is computed and compared to a second one obtained with the chemistry module deactivated. The latter represents the evolution of a passive tracer. This permits the assessment of the impact of the ozone chemistry on the temporal evolution of tropospheric columns (1000-225 hPa). The difference between the 2 free simulations after $12 \mathrm{~h}$ is depicted in Fig. A1a. We remark that the ozone partial column is decreased by $0.3 \mathrm{DU}$ with regards to the global average, by a maximum of $1.8 \mathrm{DU}$ at the tropics, where the relaxation term is stronger due to the larger departures from the climatology. These values can be compared with the increments produced by the observations assimilated in the analysis during the same time window (Fig. A1b, c). Increments are spread globally and peak at about $8 \mathrm{DU}$ in magnitude. This example supports the hypothesis that the chemistry relaxation term plays a relatively minor role, given the global coverage of IASI observations.


Fig. A1. Variability of ozone tropospheric columns (1000-225 hPa) during one assimilation window (12 h) on 5 July 2008: (a) difference between a free simulation with linear ozone chemistry and a free simulation with chemistry deactivated (passive tracer) after $12 \mathrm{~h}$ of integration, (b) increments added at 00:00 UTC by the assimilation of satellite observations, (c) IASI observations assimilated during the first window (00:00-12:00 UTC). IASI values are computed as in Fig. 3. Dark blue/red colors in (a) and (b) are reserved for values lower/greater than -6/6 DU. Dark blue/purple colors in (c) are reserved for values lower/greater than $9.1 / 50 \mathrm{DU}$. 
Acknowledgements. This work was supported by the MACC, MACCII projects (funded by the European Commission under the EU Seventh Research Framework Programme, contract number 218793), the ADOMOCA project (funded by the French LEFE INSU program) and the TOSCA program (funded by the French CNES aerospace agency). We thank NASA for providing MLS and OMI satellite ozone products. OMI analyses used in this paper were produced with the Giovanni online data system, developed and maintained by the NASA GES DISC. We acknowledge the Ether French atmospheric database (http://ether.ipsl.jussieu.fr) for providing IASI data and the NOAA ESRL Global Monitoring Division (http://esrl.noaa.gov/gmd) for providing surface ozone measurements. We acknowledge the strong support of the European Commission, Airbus, and the Airlines that carried the MOZAIC equipment free of charge and performed the maintenance since 1994. MOZAIC was funded by CNRS-INSU, Meteo-France, and FZJ (Forschungszentrum Julich, Germany). We thank all the individual agencies that provided ozonesonde data through the World Ozone and Ultraviolet Radiation Data Centre (WOUDC).

Edited by: W. Lahoz

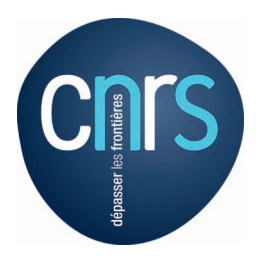

The publication of this article is financed by CNRS-INSU.

\section{References}

Ambrose, J., Reidmiller, D., and Jaffe, D.: Causes of high $\mathrm{O}_{3}$ in the lower free troposphere over the Pacific Northwest as observed at the Mt. Bachelor Observatory, Atmos. Environ., 45, 5302-5315, doi:10.1016/j.atmosenv.2011.06.056, 2011.

Avnery, S., Mauzerall, D. L., Liu, J., and Horowitz, L. W.: Global crop yield reductions due to surface ozone exposure: 2. Year 2030 potential crop production losses and economic damage under two scenarios of $\mathrm{O}_{3}$ pollution, Atmos. Environ., 45, 22972309, doi:10.1016/j.atmosenv.2011.01.002, 2011.

Balis, D., Kroon, M., Koukouli, M. E., Brinksma, E. J., Labow, G., Veefkind, J. P., and McPeters, R. D.: Validation of Ozone Monitoring Instrument total ozone column measurements using Brewer and Dobson spectrophotometer groundbased observations, J. Geophys. Res.-Atmos., 112, D24S46, doi:10.1029/2007JD008796, 2007.

Barré, J., Peuch, V.-H., Attié, J.-L., El Amraoui, L., Lahoz, W. A., Josse, B., Claeyman, M., and Nédélec, P.: Stratospheretroposphere ozone exchange from high resolution MLS ozone analyses, Atmos. Chem. Phys., 12, 6129-6144, doi:10.5194/acp12-6129-2012, 2012.

Barré, J., Peuch, V.-H., Lahoz, W. a., Attié, J.-L., Josse, B., Piacentini, A., Eremenko, M., Dufour, G., Nedelec, P., von Clarmann, T., and El Amraoui, L.: Combined data assimilation of ozone tropospheric columns and stratospheric profiles in a high-resolution CTM, Q. J. Roy. Meteorol. Soc., doi:10.1002/qj.2176, 2013.

Barret, B., Le Flochmoen, E., Sauvage, B., Pavelin, E., Matricardi, M., and Cammas, J. P.: The detection of post-monsoon tropo- spheric ozone variability over south Asia using IASI data, Atmos. Chem. Phys., 11, 9533-9548, doi:10.5194/acp-11-95332011, 2011.

Bousserez, N., Attié, J. L., Peuch, V. H., Michou, M., Pfister, G., Edwards, D., Emmons, L., Mari, C., Barret, B., Arnold, S. R., Heckel, A., Richter, A., Schlager, H., Lewis, A., Avery, M., Sachse, G., Browell, E. V., and Hair, J. W.: Evaluation of the MOCAGE chemistry transport model during the ICARTT/ITOP experiment, J. Geophys. Res.-Atmos., 112, D10S42, doi:10.1029/2006JD007595, 2007.

Boynard, A., Clerbaux, C., Coheur, P.-F., Hurtmans, D., Turquety, S., George, M., Hadji-Lazaro, J., Keim, C., and MeyerArnek, J.: Measurements of total and tropospheric ozone from IASI: comparison with correlative satellite, ground-based and ozonesonde observations, Atmos. Chem. Phys., 9, 6255-6271, doi:10.5194/acp-9-6255-2009, 2009.

Brunekreef, B. and Holgate, S. T.: Air pollution and health, Lancet, 360, 1233-1242, doi:10.1016/S0140-6736(02)11274-8, 2002.

Cariolle, D. and Teyssèdre, H.: A revised linear ozone photochemistry parameterization for use in transport and general circulation models: multi-annual simulations, Atmos. Chem. Phys., 7, $2183-$ 2196, doi:10.5194/acp-7-2183-2007, 2007.

Clerbaux, C., Boynard, A., Clarisse, L., George, M., Hadji-Lazaro, J., Herbin, H., Hurtmans, D., Pommier, M., Razavi, A., Turquety, S., Wespes, C., and Coheur, P.-F.: Monitoring of atmospheric composition using the thermal infrared IASI/MetOp sounder, Atmos. Chem. Phys., 9, 6041-6054, doi:10.5194/acp-9-6041-2009, 2009.

Coman, A., Foret, G., Beekmann, M., Eremenko, M., Dufour, G., Gaubert, B., Ung, A., Schmechtig, C., Flaud, J.-M., and Bergametti, G.: Assimilation of IASI partial tropospheric columns with an Ensemble Kalman Filter over Europe, Atmos. Chem. Phys., 12, 2513-2532, doi:10.5194/acp-12-2513-2012, 2012.

Dee, D. P. and Uppala, S.: Variational bias correction of satellite radiance data in the ERA-Interim reanalysis, Q. J. Roy. Meteorol. Soc., 1841, 1830-1841, doi:10.1002/qj, 2009.

Dee, D. P., Uppala, S. M., Simmons, A. J., Berrisford, P., Poli, P., Kobayashi, S., Andrae, U., Balmaseda, M. A., Balsamo, G., Bauer, P., Bechtold, P., Beljaars, A. C. M., van de Berg, L., Bidlot, J., Bormann, N., Delsol, C., Dragani, R., Fuentes, M., Geer, A. J., Haimberger, L., Healy, S. B., Hersbach, H., Hólm, E. V., Isaksen, L., Kå llberg, P., Köhler, M., Matricardi, M., McNally, A. P., Monge-Sanz, B. M., Morcrette, J.-J., Park, B.-K., Peubey, C., de Rosnay, P., Tavolato, C., Thépaut, J.-N., and Vitart, F.: The ERA-Interim reanalysis: configuration and performance of the data assimilation system, Q. J. Roy. Meteorol. Soc., 137, 553597, doi:10.1002/qj.828, 2011.

de Laat, A. T. J., Landgraf, J., Aben, I., Hasekamp, O., and Bregman, B.: Validation of Global Ozone Monitoring Experiment ozone profiles and evaluation of stratospheric transport in a global chemistry transport model, J. Geophys. Res., 112, D05301, doi:10.1029/2005JD006789, 2007.

Desroziers, G., Berre, L., Chapnik, B., and Poli, P.: Diagnosis of observation, background and analysis-error statistics in observation space, Q. J. Roy. Meteorol. Soc., 131, 3385-3396, doi:10.1256/qj.05.108, 2005.

Doughty, D. C., Thompson, A. M., Schoeberl, M. R., Stajner, I., Wargan, K., and Hui, W. C. J.: An intercomparison of tropospheric ozone retrievals derived from two Aura instruments and 
measurements in western North America in 2006, J. Geophys. Res.-Atmos., 116, D06303, doi:10.1029/2010JD014703, 2011.

Dufour, A., Amodei, M., Ancellet, G., and Peuch, V.-H.: Observed and modelled chemical weather during ESCOMPTE, Atmos. Res., 74, 161-189, doi:10.1016/j.atmosres.2004.04.013, 2005.

Dufour, G., Eremenko, M., Griesfeller, A., Barret, B., LeFlochmoën, E., Clerbaux, C., Hadji-Lazaro, J., Coheur, P.-F., and Hurtmans, D.: Validation of three different scientific ozone products retrieved from IASI spectra using ozonesondes, Atmos. Meas. Tech., 5, 611-630, doi:10.5194/amt-5-611-2012, 2012.

El Amraoui, L., Attié, J.-L., Semane, N., Claeyman, M., Peuch, V.H., Warner, J., Ricaud, P., Cammas, J.-P., Piacentini, A., Josse, B., Cariolle, D., Massart, S., and Bencherif, H.: Midlatitude stratosphere - troposphere exchange as diagnosed by $\mathrm{MLS} \mathrm{O}_{3}$ and MOPITT CO assimilated fields, Atmos. Chem. Phys., 10, 2175-2194, doi:10.5194/acp-10-2175-2010, 2010.

Eremenko, M., Dufour, G., Foret, G., Keim, C., Orphal, J., Beekmann, M., Bergametti, G., and Flaud, J. M.: Tropospheric ozone distributions over Europe during the heat wave in July 2007 observed from infrared nadir spectra recorded by IASI, Geophys. Res. Lett., 35, L18805, doi:10.1029/2008GL034803, 2008.

Eskes, H. J. and Boersma, K. F.: Averaging kernels for DOAS totalcolumn satellite retrievals, Atmos. Chem. Phys., 3, 1285-1291, doi:10.5194/acp-3-1285-2003, 2003.

Fioletov, V. E., Bodeker, G. E., Miller, A. J., McPeters, R. D., and Stolarski, R.: Global and zonal total ozone variations estimated from ground-based and satellite measurements: 1964-2000, J. Geophys. Res.-Atmos., 107, 4647, doi:10.1029/2001JD001350, 2002.

Fisher, M. and Andersson, E.: Developments in 4D-Var and Kalman filtering, in: Technical Memorandum Research Departement, ECMWF, Reading, United Kingdom, 2001.

Froidevaux, L., Jiang, Y. B., Lambert, A., Livesey, N. J., Read, W. G., Waters, J. W., Browell, E. V., Hair, J. W., Avery, M. A., McGee, T. J., Twigg, L. W., Sumnicht, G. K., Jucks, K. W., Margitan, J. J., Sen, B., Stachnik, R. A., Toon, G. C., Bernath, P. F., Boone, C. D., Walker, K. A., Filipiak, M. J., Harwood, R. S., Fuller, R. A., Manney, G. L., Schwartz, M. J., Daffer, W. H., Drouin, B. J., Cofield, R. E., Cuddy, D. T., Jarnot, R. F., Knosp, B. W., Perun, V. S., Snyder, W. V., Stek, P. C., Thurstans, R. P., and Wagner, P. A.: Validation of Aura Microwave Limb Sounder stratospheric ozone measurements, J. Geophys. Res., 113, D15S20, doi:10.1029/2007JD008771, 2008.

Geer, A. J., Lahoz, W. A., Bekki, S., Bormann, N., Errera, Q., Eskes, H. J., Fonteyn, D., Jackson, D. R., Juckes, M. N., Massart, S., Peuch, V.-H., Rharmili, S., and Segers, A.: The ASSET intercomparison of ozone analyses: method and first results, Atmos. Chem. Phys., 6, 5445-5474, doi:10.5194/acp-6-5445-2006, 2006.

Geer, A. J., Lahoz, W. A., Jackson, D. R., Cariolle, D., and McCormack, J. P.: Evaluation of linear ozone photochemistry parametrizations in a stratosphere-troposphere data assimilation system, Atmos. Chem. Phys., 7, 939-959, doi:10.5194/acp-7939-2007, 2007.

Guenther, A., Hewitt, C. N., Erickson, D., Fall, R., Geron, C., Graedel, T., Harley, P., Klinger, L., Lerdau, M., Mckay, W. A., Pierce, T., Scholes, B., Steinbrecher, R., Tallamraju, R., Taylor, J., and Zimmerman, P.: A global model of natural volatile organic compound emissions, J. Geophys. Res.-Atmos., 100, 8873-8892, doi:10.1029/94JD02950, 1995.

Han, W. and McNally, A. P.: The 4D-Var assimilation of ozonesensitive infrared radiances measured by IASI, Q. J. Roy. Meteorol. Soc., 136, 2025-2037, doi:10.1002/qj.708, 2010.

Hegarty, J., Mao, H., and Talbot, R.: Winter- and summertime continental influences on tropospheric $\mathrm{O}_{3}$ and $\mathrm{CO}$ observed by TES over the western North Atlantic Ocean, Atmos. Chem. Phys., 10, 3723-3741, doi:10.5194/acp-10-3723-2010, 2010.

Inness, A., Baier, F., Benedetti, A., Bouarar, I., Chabrillat, S., Clark, H., Clerbaux, C., Coheur, P., Engelen, R. J., Errera, Q., Flemming, J., George, M., Granier, C., Hadji-Lazaro, J., Huijnen, V., Hurtmans, D., Jones, L., Kaiser, J. W., Kapsomenakis, J., Lefever, K., Leitão, J., Razinger, M., Richter, A., Schultz, M. G., Simmons, A. J., Suttie, M., Stein, O., Thépaut, J.-N., Thouret, V., Vrekoussis, M., Zerefos, C., and the MACC team: The MACC reanalysis: an $8 \mathrm{yr}$ data set of atmospheric composition, Atmos. Chem. Phys., 13, 4073-4109, doi:10.5194/acp-13-4073-2013, 2013.

Jackson, D. R.: Assimilation of EOS MLS ozone observations in the Met Office data-assimilation system, Q. J. Roy. Meteorol. Soc., 133, 1771-1788, doi:10.1002/qj.140, 2007.

Jackson, D. R. and Orsolini, Y. J.: Estimation of Arctic ozone loss in winter 2004 / 05 based on assimilation of EOS MLS and SBUV / 2 observations, Q. J. Roy. Meteorol. Soc., 134, 1833-1841, doi:10.1002/qj.316, 2008.

Jaffe, D. and Ray, J.: Increase in surface ozone at rural sites in the western US, Atmos. Environ., 41, 5452-5463, doi:10.1016/j.atmosenv.2007.02.034, http://linkinghub.elsevier. com/retrieve/pii/S1352231007001598, 2007.

Josse, B., Simon, P., and Peuch, V.: Radon global simulations with the multiscale chemistry and transport model MOCAGE, Tellus B, 56, 339-356, doi:10.1111/j.1600-0889.2004.00112.x, 2004.

Kar, J., Fishman, J., Creilson, J. K., Richter, A., Ziemke, J., and Chandra, S.: Are there urban signatures in the tropospheric ozone column products derived from satellite measurements?, Atmos. Chem. Phys., 10, 5213-5222, doi:10.5194/acp-10-5213-2010, 2010.

Komhyr, W. D., Barnes, R. A., Brothers, G. B., Lathrop, J. A., and Opperman, D. P.: Electrochemical concentration cell ozonesonde performance evaluation during STOIC 1989, J. Geophys. Res.Atmos., 100, 9231-9244, doi:10.1029/94JD02175, 1995.

Lahoz, W. A., Errera, Q., Swinbank, R., and Fonteyn, D.: Data assimilation of stratospheric constituents: a review, Atmos. Chem. Phys., 7, 5745-5773, doi:10.5194/acp-7-5745-2007, 2007a.

Lahoz, W. A., Geer, A. J., Bekki, S., Bormann, N., Ceccherini, S., Elbern, H., Errera, Q., Eskes, H. J., Fonteyn, D., Jackson, D. R., Khattatov, B., Marchand, M., Massart, S., Peuch, V.-H., Rharmili, S., Ridolfi, M., Segers, A., Talagrand, O., Thornton, H. E., Vik, A. F., and von Clarmann, T.: The Assimilation of Envisat data (ASSET) project, Atmos. Chem. Phys., 7, 1773-1796, doi:10.5194/acp-7-1773-2007, 2007b.

Lamarque, J.-F., Khattatov, B. V., and Gille, J. C.: Constraining tropospheric ozone column through data assimilation, J. Geophys. Res., 107, 4651, doi:10.1029/2001JD001249, 2002.

Levelt, P. F., Oord, G. H. J. V. D., Dobber, M. R., Mälkki, A., Visser, H., Vries, J. D., Stammes, P., Lundell, J. O. V., and Saari, H.: The Ozone Monitoring Instrument, IEEE T. Geosci. Remote Sens., 44, 1093-1101, doi:10.1109/TGRS.2006.872333, 2006. 
Livesey, N. J., Filipiak, M. J., Froidevaux, L., Read, W. G., Lambert, A., Santee, M. L., Jiang, J. H., Pumphrey, H. C., Waters, J. W., Cofield, R. E., Cuddy, D. T., Daffer, W. H., Drouin, B. J., Fuller, R. A., Jarnot, R. F., Jiang, Y. B., Knosp, B. W., Li, Q. B., Perun, V. S., Schwartz, M. J., Snyder, W. V., Stek, P. C., Thurstans, R. P., Wagner, P. A., Avery, M., Browell, E. V., Cammas, J.-P., Christensen, L. E., Diskin, G. S., Gao, R.-S., Jost, H.-J., Loewenstein, M., Lopez, J. D., Nedelec, P., Osterman, G. B., Sachse, G. W., and Webster, C. R.: Validation of Aura Microwave Limb Sounder $\mathrm{O}_{3}$ and $\mathrm{CO}$ observations in the upper troposphere and lower stratosphere, J. Geophys. Res., 113, D15S02, doi:10.1029/2007JD008805, 2008.

Ma, J. and van Aardenne, J. A.: Impact of different emission inventories on simulated tropospheric ozone over China: a regional chemical transport model evaluation, Atmos. Chem. Phys., 4, 877-887, doi:10.5194/acp-4-877-2004, 2004.

Marenco, A., Thouret, V., Nédélec, P., Smit, H., Helten, M., Kley, D., Karcher, F., Simon, P., Law, K., Pyle, J., Poschmann, G., Rainer, V. W., Hume, C., and Cook, T.: Measurement of ozone and water vapor by Airbus in-service aircraft: The MOZAIC airborne program, an overview, J. Geophys. Res.-Atmos., 103, 25631-25642, doi:10.1029/98JD00977, 1998.

Massart, S., Clerbaux, C., Cariolle, D., Piacentini, A., Turquety, S., and Hadji-Lazaro, J.: First steps towards the assimilation of IASI ozone data into the MOCAGE-PALM system, Atmos. Chem. Phys., 9, 5073-5091, doi:10.5194/acp-9-5073-2009, 2009.

Massart, S., Pajot, B., Piacentini, A., and Pannekoucke, O.: On the Merits of Using a 3D-FGAT Assimilation Scheme with an Outer Loop for Atmospheric Situations Governed by Transport, Mon. Weather Rev., 138, 4509-4522, doi:10.1175/2010MWR3237.1, 2010.

Massart, S., Piacentini, A., and Pannekoucke, O.: Importance of using ensemble estimated background error covariances for the quality of atmospheric ozone analyses, Q. J. Roy. Meteorol. Soc., 138, 889-905, doi:10.1002/qj.971, 2012.

Miyazaki, K., Eskes, H. J., Sudo, K., Takigawa, M., van Weele, M., and Boersma, K. F.: Simultaneous assimilation of satellite $\mathrm{NO}_{2}$, $\mathrm{O}_{3}, \mathrm{CO}$, and $\mathrm{HNO}_{3}$ data for the analysis of tropospheric chemical composition and emissions, Atmos. Chem. Phys., 12, 95459579, doi:10.5194/acp-12-9545-2012, 2012.

Oltmans, S. J., Lefohn, A. S., Harris, J. M., Galbally, I., Scheel, H. E., Bodeker, G., Brunke, E., Claude, H., Tarasick, D., Johnson, B. J., Simmonds, P., Shadwick, D., Anlauf, K., Hayden, K., Schmidlin, F., Fujimoto, T., Akagi, K., Meyer, C., Nichol, S., Davies, J., Redondas, A., and Cuevas, E.: Long-term changes in tropospheric ozone, Atmos. Environ., 40, 3156-3173, doi:10.1016/j.atmosenv.2006.01.029, 2006.

Pannekoucke, O. and Massart, S.: Estimation of the local diffusion tensor and normalization for heterogeneous correlation modelling using a diffusion equation, Q. J. Roy. Meteorol. Soc., 14, 1-14, doi:10.1002/qj.288, 2008.

Parrington, M., Jones, D. B. a., Bowman, K. W., Horowitz, L. W., Thompson, a. M., Tarasick, D. W., and Witte, J. C.: Estimating the summertime tropospheric ozone distribution over North America through assimilation of observations from the Tropospheric Emission Spectrometer, J. Geophys. Res., 113, D18307, doi:10.1029/2007JD009341, 2008.

Parrington, M., Jones, D. B. A., Bowman, K. W., Thompson, A. M., Tarasick, D. W., Merrill, J., Oltmans, S. J., Leblanc, T.,
Witte, J. C., and Millet, D. B.: Impact of the assimilation of ozone from the Tropospheric Emission Spectrometer on surface ozone across North America, Geophys. Res. Lett., 36, L04802, doi:10.1029/2008GL036935, 2009.

Paul, J., Fortuin, F., and Kelder, H.: An ozone climatology based on ozonesonde and satellite measurements, J. Geophys. Res.Atmos., 103, 31709-31734, doi:10.1029/1998JD200008, 1998.

Petropavlovskikh, I. and Oltmans, S.: Troposheric Ozone measurements, 1973-2011, Tech. rep., NOAA, ftp://aftp.cmdl.noaa.gov/ data/ozone/in-situ/, 2012.

Peuch, V.-H., Amodei, M., Barthet, T., Cathala, M. L., Michou, M., and Simon, P.: MOCAGE, MOdèle de Chimie Atmosphérique à Grande Echelle, in: Proceedings of Météo France: Workshop on atmospheric modelling, 33-36, Toulouse, France, 1999.

Remer, L. A., Kleidman, R. G., Levy, R. C., Kaufman, Y. J., Tanré, D., Mattoo, S., Martins, J. V., Ichoku, C., Koren, I., Yu, H., and Holben, B. N.: Global aerosol climatology from the MODIS satellite sensors, J. Geophys. Res., 113, 1-18, doi:10.1029/2007JD009661, 2008.

Seinfeld, J. H. and Pandis, S. N.: Atmospheric Chemistry and Physics: From Air Pollution to Climate Change, John Wiley \& Sons, New York, 1998.

Solomon, S., Qin, D., Manning, M., Chen, Z., Marquis, M., Averyt, K., Tignor, M., and Miller, H. L.: Contribution of Working Group I to the Fourth Assessment Report of the Intergovernmental Panel on Climate Change, Vol. 446, Cambridge University Press, NY, 2007.

Stajner, I., Wargan, K., Pawson, S., Hayashi, H., Chang, L.-P., Hudman, R. C., Froidevaux, L., Livesey, N., Levelt, P. F., Thompson, A. M., Tarasick, D. W., Stübi, R., Andersen, S. B., Yela, M., König-Langlo, G., Schmidlin, F. J., and Witte, J. C.: Assimilated ozone from EOS-Aura: Evaluation of the tropopause region and tropospheric columns, J. Geophys. Res., 113, D16S32, doi:10.1029/2007JD008863, 2008.

Stohl, A., Bonasoni, P., Cristofanelli, P., Collins, W., Feichter, J., Frank, A., Forster, C., Gerasopoulos, E., Gäggeler, H., James, P., Kentarchos, T., Kromp-Kolb, H., Krüger, B., Land, C., Meloen, J., Papayannis, A., Priller, A., Seibert, P., Sprenger, M., Roelofs, G. J., Scheel, H. E., Schnabel, C., Siegmund, P., Tobler, L., Trickl, T., Wernli, H., Wirth, V., Zanis, P., and Zerefos, C.: Stratosphere-troposphere exchange: A review, and what we have learned from STACCATO, J. Geophys. Res.-Atmos., 108, 8516, doi:10.1029/2002JD002490, 2003.

Tang, Q. and Prather, M. J.: Five blind men and the elephant: what can the NASA Aura ozone measurements tell us about stratosphere-troposphere exchange?, Atmos. Chem. Phys., 12, 2357-2380, doi:10.5194/acp-12-2357-2012, 2012.

Tanimoto, H.: Increase in springtime tropospheric ozone at a mountainous site in Japan for the period 1998-2006, Atmos. Environ., 43, 1358-1363, 2009.

Teyssèdre, H., Michou, M., Clark, H. L., Josse, B., Karcher, F., Olivié, D., Peuch, V.-H., Saint-Martin, D., Cariolle, D., Attié, J.-L., Nédélec, P., Ricaud, P., Thouret, V., van der A, R. J., VolzThomas, A., and Chéroux, F.: A new tropospheric and stratospheric Chemistry and Transport Model MOCAGE-Climat for multi-year studies: evaluation of the present-day climatology and sensitivity to surface processes, Atmos. Chem. Phys., 7, 58155860, doi:10.5194/acp-7-5815-2007, 2007. 
Thompson, A. M., Witte, J. C., McPeters, R. D., Oltmans, S. J., Schmidlin, F. J., Logan, J. A., Fujiwara, M., Kirchhoff, V. W. J. H., Posny, F., Coetzee, G. J. R., Hoegger, B., Kawakami, S., Ogawa, T., Johnson, B. J., Vömel, H., and Labow, G.: Southern Hemisphere Additional Ozonesondes (SHADOZ) 19982000 tropical ozone climatology 1. Comparison with Total Ozone Mapping Spectrometer (TOMS) and ground-based measurements, J. Geophys. Res.-Atmos., 108, 8238, doi:10.1029/2001JD000967, 2003.

van $\operatorname{der}$ A, R. J., Allaart, M. A. F., and Eskes, H. J.: Multi sensor reanalysis of total ozone, Atmos. Chem. Phys., 10, 11277-11294, doi:10.5194/acp-10-11277-2010, 2010.

van der Werf, G. R., Randerson, J. T., Giglio, L., Collatz, G. J., Kasibhatla, P. S., and Arellano Jr., A. F.: Interannual variability in global biomass burning emissions from 1997 to 2004, Atmos. Chem. Phys., 6, 3423-3441, doi:10.5194/acp-6-3423-2006, 2006.

Veefkind, J. P., de Haan, J. F., Brinksma, E. J., Kroon, M., and Levelt, P. F.: Total ozone from the ozone monitoring instrument (OMI) using the DOAS technique, IEEE T. Geosci. Remote Sens., 44, 1239-1244, doi:10.1109/TGRS.2006.871204, 2006.

Waters, J. W., Froidevaux, L., Harwood, R. S., Jarnot, R. F., Pickett, H. M., Read, W. G., Siegel, P. H., Cofield, R. E., Filipiak, M. J., Flower, D. A., Holden, J. R., Lau, G. K., Livesey, N. J., Manney, G. L., Pumphrey, H. C., Santee, M. L., Wu, D. L., Cuddy, D. T., Lay, R. R., Loo, M. S., Perun, V. S., Schwartz, M. J., Stek, P. C., Thurstans, R. P., Boyles, M. A., Chandra, K. M., Chavez, M. C., Chen, G.-S., Chudasama, B. V., Dodge, R., Fuller, R. A., Girard, M. A., Jiang, J. H., Jiang, Y., Knosp, B. W., LaBelle, R. C., Lam, J. C., Lee, K. A., Miller, D., Oswald, J. E., Patel, N. C., Pukala, D. M., Quintero, O., Scaff, D. M., Van Snyder, W., Tope, M. C., Wagner, P. A., and Walch, M. J.: The Earth observing system microwave limb sounder (EOS MLS) on the aura Satellite, IEEE T. Geosci. Remote Sens., 44, 1075-1092, doi:10.1109/TGRS.2006.873771, 2006.

Weaver, A. and Courtier, P.: Correlation modelling on the sphere using a generalized diffusion equation, Q. J. Roy. Meteorol. Soc., 127, 1815-1846, http://onlinelibrary.wiley.com/doi/10.1002/qj. 49712757518/abstract, 2001.
Yang, Q., Cunnold, D. M., Choi, Y., Wang, Y., Nam, J., Wang, H.J., Froidevaux, L., Thompson, A. M., and Bhartia, P. K.: A study of tropospheric ozone column enhancements over North America using satellite data and a global chemical transport model, J. Geophys. Res., 115, D08302, doi:10.1029/2009JD012616, 2010.

Zhang, L., Jacob, D. J., Boersma, K. F., Jaffe, D. A., Olson, J. R., Bowman, K. W., Worden, J. R., Thompson, A. M., Avery, M. A., Cohen, R. C., Dibb, J. E., Flock, F. M., Fuelberg, H. E., Huey, L. G., McMillan, W. W., Singh, H. B., and Weinheimer, A. J.: Transpacific transport of ozone pollution and the effect of recent Asian emission increases on air quality in North America: an integrated analysis using satellite, aircraft, ozonesonde, and surface observations, Atmos. Chem. Phys., 8, 6117-6136, doi:10.5194/acp-8-6117-2008, 2008.

Zhang, L., Jacob, D. J., Liu, X., Logan, J. A., Chance, K., Eldering, A., and Bojkov, B. R.: Intercomparison methods for satellite measurements of atmospheric composition: application to tropospheric ozone from TES and OMI, Atmos. Chem. Phys., 10, 4725-4739, doi:10.5194/acp-10-4725-2010, 2010.

Ziemke, J. R., Chandra, S., Duncan, B. N., Froidevaux, L., Bhartia, P. K., Levelt, P. F., and Waters, J. W.: Tropospheric ozone determined from Aura OMI and MLS: Evaluation of measurements and comparison with the Global Modeling Initiative's Chemical Transport Model, J. Geophys. Res., 111, D19303, doi:10.1029/2006JD007089, 2006.

Ziemke, J. R., Chandra, S., Duncan, B. N., Schoeberl, M. R., Torres, O., Damon, M. R., and Bhartia, P. K.: Recent biomass burning in the tropics and related changes in tropospheric ozone, Geophys. Res. Lett., 36, L15819, doi:10.1029/2009GL039303, 2009.

Ziemke, J. R., Chandra, S., Labow, G. J., Bhartia, P. K., Froidevaux, L., and Witte, J. C.: A global climatology of tropospheric and stratospheric ozone derived from Aura OMI and MLS measurements, Atmos. Chem. Phys., 11, 9237-9251, doi:10.5194/acp11-9237-2011, 2011. 